\title{
Capacity Creation in Basic-Materials Industries
}

THE ADEQUACY of industrial capacity has not been a central concern of postwar stabilization policy. Aggregate-demand targets, such as potential gross national product, have typically been defined with reference only to labor-market conditions. While emphasizing the balance between supply and demand, most studies of inflation have taken the unemployment rate of labor as the primary measure of resource utilization. Although there has been considerable interest in tax and monetary measures to promote investment, they often have been used within a policy framework that focuses on short-run aggregate-demand objectives rather than on future increments to capacity.

The emphasis upon demand rather than supply in stabilization policy reflects, in part, the conclusions of prior empirical studies. Many inflation studies have attributed a relatively minor role to cyclical fluctuations in capacity utilization, broadly measured, and serious difficulties arise in defining a measurable concept of aggregate capacity. Previously observed variations in aggregate investment rates also appear to have had only modest effects upon the growth of output per manhour and thus the growth of potential output.

Note: I am grateful to James Altman, Merriann M. Panarella, and Andrea V. Mills for research assistance in the preparation of this report. Daryl Smith, of Temple, Barker, and Sloane, Inc., and Peter Oliver, of Arthur D. Little, Inc., were generous in answering questions about their reports to the Environmental Protection Agency. Also, I would like to thank Lawrence Forest of the Federal Reserve Board staff for data and information about capacity measures. 
The experience of severe shortages and large price increases for some commodities in 1973-74, however, has given rise to widespread discussions of the scarcity of industrial capacity and forecasts of a recurrence of the 1973 supply difficulties as the current expansion continues. In addition, sharp increases in costs of capital goods, of pollution abatement, and of borrowing have stirred doubts about the ability of industry to expand capacity to meet future needs.

On the other hand, notions of a general capacity shortage were challenged in a previous article in this journal by George Perry. ${ }^{1}$ He examined the analytical value of the three major measures of the utilization rate, compiled by the Federal Reserve Board, McGraw-Hill, and the Wharton School economic forecasting unit. Of these, only the Wharton index, based on extrapolation of past trends, appeared to indicate serious capacity pressures in 1973. The McGraw-Hill index, which Perry found reliable in a variety of analytical applications, remained significantly below its 1966 peak of 91 percent. And even Perry's finding of a modest slowing of capacity growth in manufacturing after 1966 is largely eliminated by recent upward revisions in the production indexes. ${ }^{2}$

More specific evidence of capacity shortages is provided by the Federal Reserve Board utilization index for basic materials, which reached a peak of 93.5 percent in 1973, a rate previously approached only for short periods in 1951 and $1966 .{ }^{3}$ While the basic-materials index accounts for only 8.5 percent of overall industrial production on a value-added basis, it represents a key set of industries and includes nearly all of those sectors for which shortages of capacity were suspected in 1973.

The behavior of prices in these industries supports the evidence of scarcity: overall, they rose 16 percent in 1973 and 35 percent in 1974. Even if refined petroleum products are excluded, the rates of increase were 11 and

1. George L. Perry, "Capacity in Manufacturing," BPEA, 3:1973, pp. 701-42.

2. One measure of aggregate manufacturing capacity can be obtained by dividing the McGraw-Hill utilization rate into the FRB index of production for December of each year. Growth in capacity, as estimated on the basis of the revised production index, gives no evidence of slowing, since it averaged 4.7 percent annually between 1955-65 and 4.6 percent for the 1965-75 period. There is, on the other hand, a slowing of the growth of capacity relative to the capital stock after 1969 . This can be attributed only in part to the inclusion of pollution-abatement expenditures in the capital stock and the induced closing of older, heavily polluting plants. But the argument that the McGraw-Hill utilization index overstated aggregate excess capacity in 1973 would magnify this implied decline in the growth of capacity relative to the capital stock with no evidence that the decline reflects greater factor substitution.

3. This index includes all or part of the following industries: steel, copper, aluminum, cement, plywood, paper and paperboard, textiles, chemicals, and petroleum refining. 
35 percent in 1973 and 1974, respectively. ${ }^{4}$ These price increases are particularly large in an historical context: the annual rise in the index averaged less than 1 percent over the 1960-70 period.

The present concern with the inadequacy of industrial capacity seems to reflect problems in 1973-74 in a relatively small set of primary-materials industries. There are several reasons for expecting capacity limitations to be most meaningful for these industries. First, they are process-related industries, in which the concept of a physical limitation on output would be expected to have the greatest significance. For much of the rest of the economy, production can be increased with a given capital stock by adding workshifts, or workers on a given shift. Costs per unit produced may rise, but probably only gradually. Thus, estimates of capacity output by individual firms, which cannot accurately project the availability of labor and other variable factors, may be a dubious concept of limited economic significance. In many of the basic-materials industries, such opportunities to expand output are more limited, because production processes are maintained around the clock normally and technological constraints limit the substitution of variable for fixed factors of production.

Second, new pollution-abatement regulations have had a pronounced impact on the primary-materials industries. Allegedly, measures taken to comply have absorbed large amounts of investment funds that otherwise would have been used to expand capacity, and uncertainty about the regulations has delayed expansion plans.

Third, these are highly capital-intensive industries, which have been particularly affected by the substantial increases in capital-goods prices in recent years. Thus, investment in new capacity may have been inhibited as firms sought more concrete evidence that product prices would rise sufficiently relative to variable costs to cover higher capital costs.

Finally, because the construction of new capacity normally requires several years, these industries face the special uncertainties of anticipating demand that long into the future. The last decade has been a chaotic period for the U.S. economy and the abrupt swings in demand between boom and bust increased the likelihood of planning mistakes that could not be quickly corrected.

4. The estimated rates of price increase are based on a constructed price index using categories of the wholesale price index that correspond as much as possible to the industries included in the basic-materials production index. The existence of price controls in 1973 may have affected the distribution of price increases between the years 1973 and 1974. 
In this paper an attempt will be made to evaluate the adequacy of capacity in three industries: steel, aluminum, and paper. These are industries in which capacity restrictions were said to be a serious problem in 1973 and whose ability to expand capacity in future years without large price increases or special government assistance has often been the subject of concern. They are also industries for which a meaningful measure of capacity is available, based upon a physical concept of machine availability. A major purpose of the study is to determine whether an examination of individual industries can offer insights into the issue of capacity growth and capital needs that are not evident in more aggregative analysis.

\section{Capacity Imbalances in 1973}

Steel, aluminum, and paper all experienced capacity problems in 197374. Yet the significance of that episode for the future depends upon one's beliefs about the factors underlying any shortgages that occurred. Some see the episode as a simple reflection of excessive aggregate-demand stimulus. Others stress the major structural changes during the period-devaluation, wage and price controls, specific shortgages induced by bad weather and the oil embargo, and a large burst of speculative activity in world commodity markets-a coincidence of special events that is unlikely to recur. On these grounds, special supply-oriented measures would not be the appropriate remedy. To still other observers, the period indicates a major crisis of inadequate capacity. They foresee expansion severely restricted because of low current profits, large increases in capital costs, the diversion of limited investment funds into pollution-abatement facilities, and the inability of firms in these industries to raise the required funds in the capital markets.

Although the circumstances of individual industries differed somewhat, several general conclusions can be drawn. First, the 1972-73 recovery was unusual in the extent to which it was an expansion led by durable goods with a consequent high demand for basic metals. While real GNP expanded 5.7 percent in 1972 and 5.3 percent in 1973, durable-goods output rose by 13.6 and 12.5 percent, respectively. As figure 1 shows, in 1973 durable-goods output reached its highest share of nonfarm business output since World War II. Moreover, the change in the share between the low of 1971 and the peak of 1973 exceeded that of the 1955 expansion and itself is exceeded only by the shift that accompanied the 1950-51 Korean War buildup. 


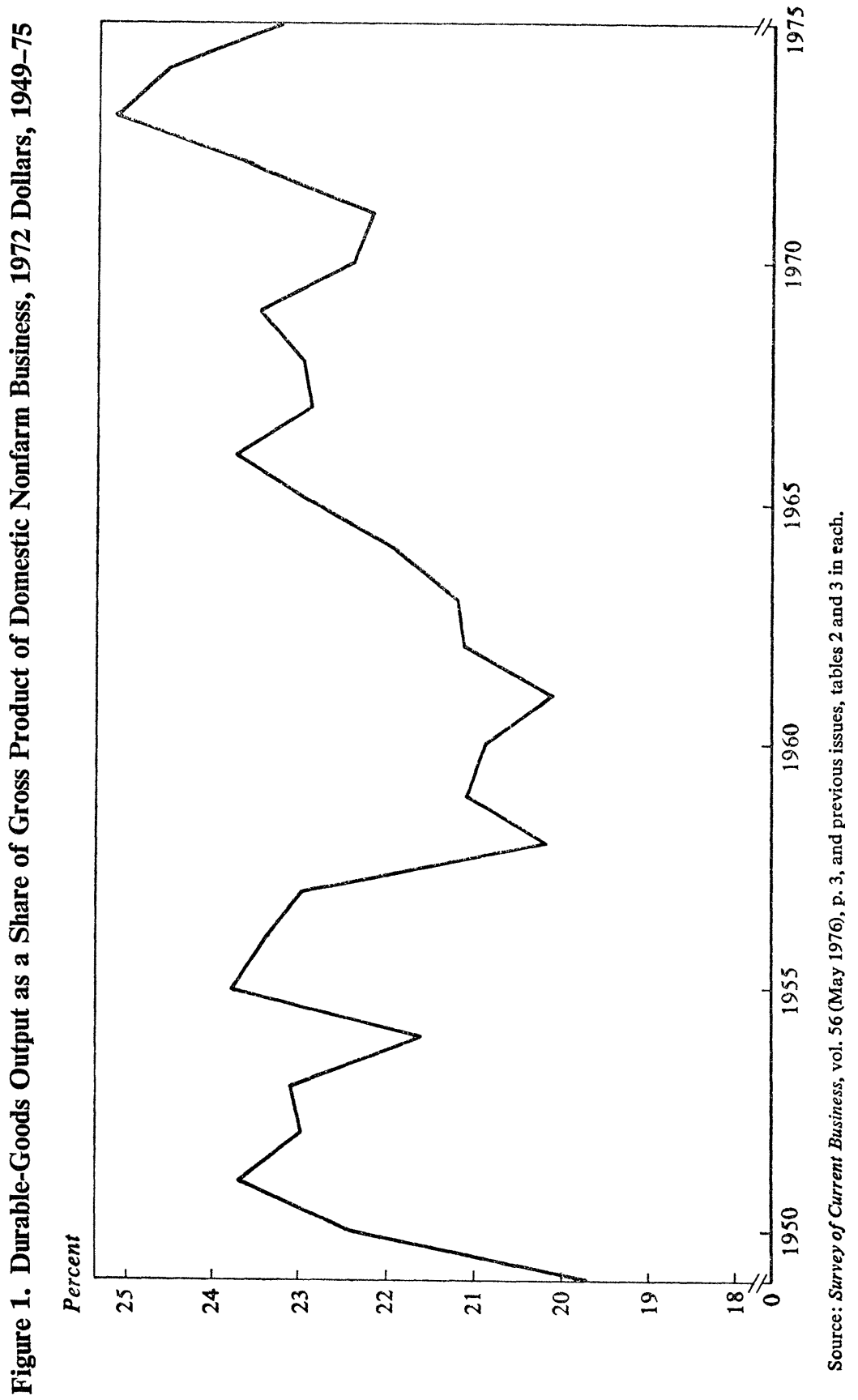


Second, by the time the demand surge came, capacity growth had slowed in all these industries; in some it had been slow for years. This slow growth may be traced to the impact of the 1970 recession upon incentives to expand; declining profitability in the late 1960s; and, perhaps, the need to meet tighter pollution standards.

Third, these general conditions were reinforced by special factors in each industry which resulted from devaluation, power shortages, a coincident worldwide economic boom, and price-wage controls. The strong demand pressures in 1973 were translated into an intense and speculative inventory buildup in early 1974 that sustained production in these industries well after the point of general economic decline; but, once the fears of shortage had passed, the accumulation of excess inventories in 1974 greatly intensified the following drop in production.

\section{STEEL}

The tight supply conditions within the steel industry in 1973 reflected the sudden and large surge in the demand for durable goods, the devaluation of the dollar in 1973, strong world demand for steel, and the absence of any significant growth in the capacity of the domestic steel industry during the previous decade.

In the years prior to 1972, most of the growth in demand was met by foreign supply. Apparent consumption of steel products rose from 81.8 million tons in 1955 to an average of 102.5 million tons in 1968-70 (see table 1). ${ }^{5}$ This amounted to an average annual growth of 1.7 percent compared with only 0.7 percent for domestic shipments over the same period; the net export position of the industry changed from a surplus of 2.9 million tons in 1955 to a deficit of 15.5 million tons in 1971, a shift equal to 21 percent of 1971 shipments. As a result of its inability to compete with foreign producers, the domestic steel industry was plagued with excess capacity throughout the 1960s and nearly all of its investment was directed toward modernizing existing facilities. The results were an increase in the capacity to produce raw steel of only 4 percent between 1960 and 1972 and a sharp shift in the composition of production toward the basic-oxygen and electric furnaces. The proportion of production accounted for by the open-hearth and Bessemer processes declined from 88 percent in 1960 to

5. Apparent consumption is defined as purchases by consuming industries. Thus it includes metal added to users' inventories as well as that consumed in production. 
24 percent in 1974. By the time of the 1971 devaluation, most of the excess capacity was eliminated and operating rates in the industry were comparable to those in the rest of manufacturing.

The steel industry was faced with a sudden and largely unanticipated rise in demand in the years 1972-74. As table 1 reveals, the strong expansion of the economy brought a 15 percent increase in domestic consumption of steel products in 1973. In addition, net imports declined sharply in both 1972 and 1973, so that domestic shipments expanded 21.4 percent in 1973. This huge growth in demand appears to have raised the utilization of steel capacity to rates matched only during the Korean War.

A simple regression relationship between apparent steel consumption and the durable-goods and construction components of GNP was estimated as a means of determining normal demand. The comparison of actual and predicted consumption implies that the growth in demand in 1972 and 1973 was fully consistent with the expansion of economic activity in industries that are heavy consumers of steel products. Changes in durablegoods output and in steel consumption of this magnitude are consistent with those in the economic recoveries of 1955 and 1959. But the pressures in 1973 were intensified by the sharp decline in net imports and the absence of a large backlog of unused capacity.

The equation implied that apparent consumption was unusually high in 1974 and abnormally low in 1975; but most of this deviation of actual from estimated consumption can be traced to inventory movements that were the direct outgrowth of the 1973 capacity pressures. ${ }^{6}$ Steel inventories of manufacturers rose 22 percent in 1974 and declined 23 percent in 1975. Thus, a speculative demand for steel (purchases in excess of immediate needs) appears to be an important explanation for the maintenance of high levels of production in 1974. A strong growth in the consumption of steel in 1973 pushed the industry to full utilization of capacity, initiated fears of shortages, and caused a burst of speculative inventory accumulation that maintained demand at high levels well into 1974. The speculative demand pressures are also evident in a backlog of unfilled orders equal to 28 percent of annual shipments at the end of 1973 compared with 15 percent and 14 percent, respectively, in the high-demand years of 1969 and 1966. The re-

6. A special survey of steel consumption and inventories in manufacturing has been reported on a monthly basis since 1961 . See Survey of Current Business, vol. 56 (June 1976), p. S-32, and previous issues. Similar data are not available for other steel consumers. 


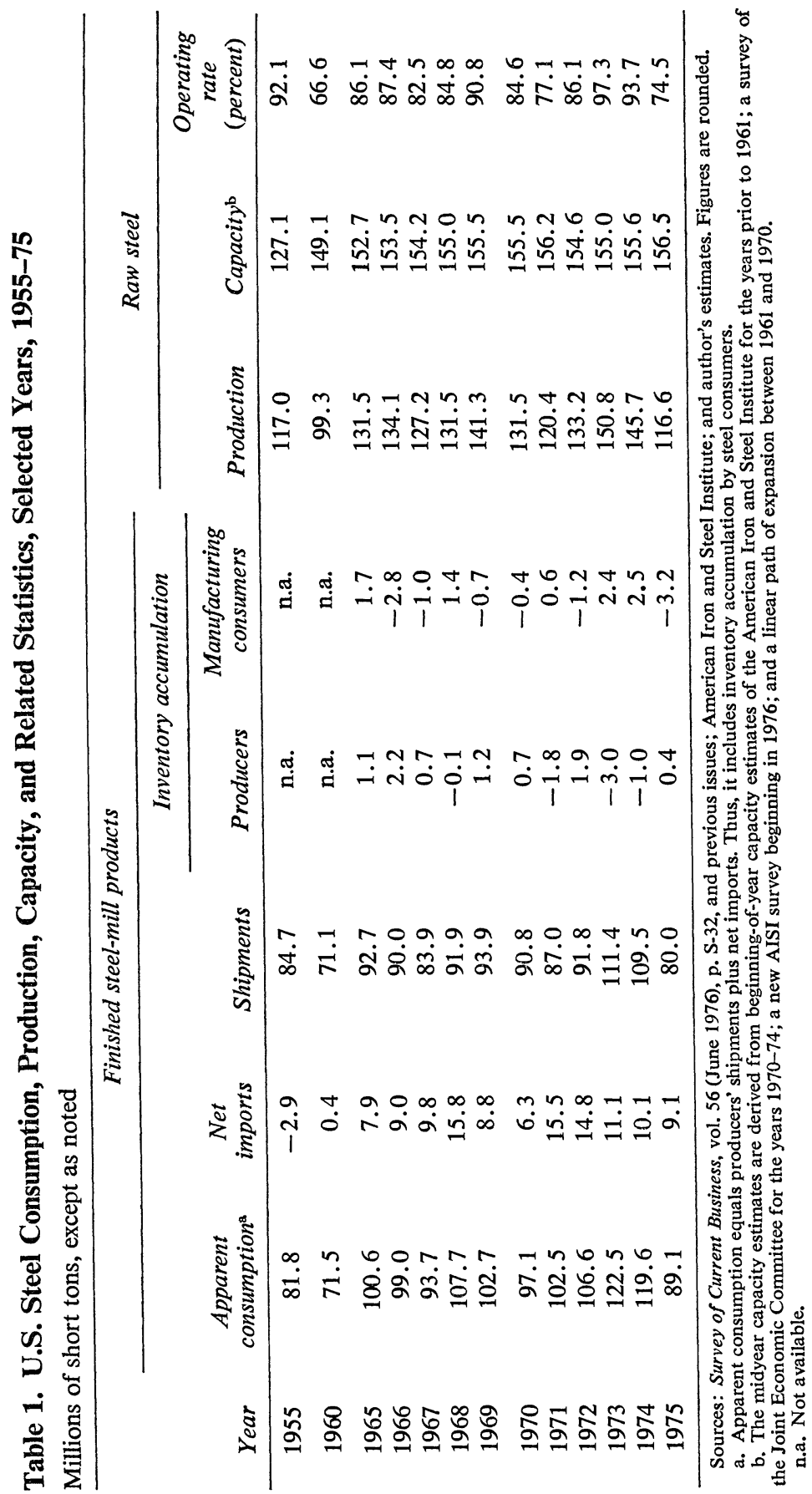


sulting buildup of excessive inventory in the face of declining general economic activity led to an enormous drop in steel shipments in 1975 to a level 28 percent below those of 1973.

Because the rest of the world was in the midst of a strong economic expansion in 1973 and also encountered tight steel capacity, it is difficult to estimate precisely the contribution of devaluation to the change in the net export position after 1971. But it appears to have been an important factor: as table 1 shows, the share of imports in domestic consumption increased very little in the 1975 recession, compared with 1973, and remained far below the share reached in 1971, the previous year of excess world capacity.

\section{ALUMINUM}

The physical capacity of plant forms a particularly rigid ceiling for production in the primary aluminum industry because reduction plants (for the conversion of alumina to aluminum) are normally operated around the clock with limited opportunities to produce in excess of rated capacity. ${ }^{7}$ In contrast to steel, domestic aluminum shipments have grown very rapidly throughout the postwar period, averaging 7.2 percent a year between 1950 and 1974. Domestic production was augmented throughout the 1950s by heavy inflows of aluminum into the government stockpile; these stocks peaked at 2 million tons in 1963, but in subsequent years government policies have changed and they have been largely depleted. In years of high demand about 75 percent of the total domestic supply is accounted for by primary production; secondary recovery (recycled scrap) and a small amount of imports provide the remainder.

In addition to the strong secular growth rate, aluminum demand is highly cyclical. As a result, the industry has had problems in accurately anticipating demand the three to four years into the future required to construct new plants. This is reflected in periodic surpluses and shortages of capacity and wide swings in its rate of growth. Spurred by government incentives, capacity expanded by 230 percent during the 1950 s, only to be utilized at an average of about 80 percent in the 1958-62 period. Capacity expanded by less than 12 percent in the first half of the 1960s and utilization rates moved up to 100 percent in 1965-67. This pressure touched off another round of

7. The estimated rates of capacity utilization shown in table 2 exceed 100 percent in some years because an average of beginning- and end-of-year capacity was used as the denominator. 
rapid growth in capacity, totaling 51 percent between 1965 and 1970, and utilization rates again fell to very low levels. In the 1970-75 period capacity grew only 19 percent.

The aluminum shortage in 1973 appeared with surprising swiftness, however. As recently as 1972 an OECD report concluded that serious problems of excess capacity would plague the world aluminum industry beyond 1975. ${ }^{8}$ The rapid shift to a situation of domestic shortages can be traced to a strong rise of aluminum demand in the United States, power shortages, and a drop in net imports. As shown in table 2, apparent domestic consumption rose by 18 percent in 1973. As with steel, this rise came largely from the concentration of the 1973 economic boom in the durable-goods industries that are heavy users of aluminum. A statistical equation relating aluminum consumption to durable-goods demand yielded results very similar to those for steel: actual and predicted consumption were nearly equal in 1972-73; but actual consumption was 8 percent above the predicted level in 1974 and 5.5 percent below that in 1975. As in the case of steel, fears of aluminum shortages led consumers to raise their orders above immediate needs, causing an excessive inventory buildup in 1974 followed by decumulation in 1975.

On the supply side, a drought in the Northwest caused reductions in hydroelectric power and major curtailments of production. This factor alone accounts for about a 7 percent loss of effective production and explains the low 1973 operating rate. In addition, the combination of devaluation of the dollar and U.S. price controls reduced net imports from the levels of 1971 and 1972. As a result of these factors, the supply available from primary and secondary production plus net imports increased by only 2.5 percent in 1973 and left a gap of 1.0 million tons of demand that had to be met out of inventory.

A reduction in producers' stocks of 248,000 tons filled a portion of the gap between demand and supply but 730,000 tons were supplied out of the government stockpiles (11 percent of consumption). Additional sales of 510 million tons ( 8 percent of consumption) in 1974 nearly exhausted the reserve.

While primary aluminum prices were subject to controls, the tight market conditions are evident in the 156 percent rise in scrap prices between December 1972 and June 1974. A strong, worldwide rise in aluminum de-

8. Organisation for Economic Co-operation and Development, Problems and Prospects of the Primary Aluminum Industry (Paris: OECD, 1973). 


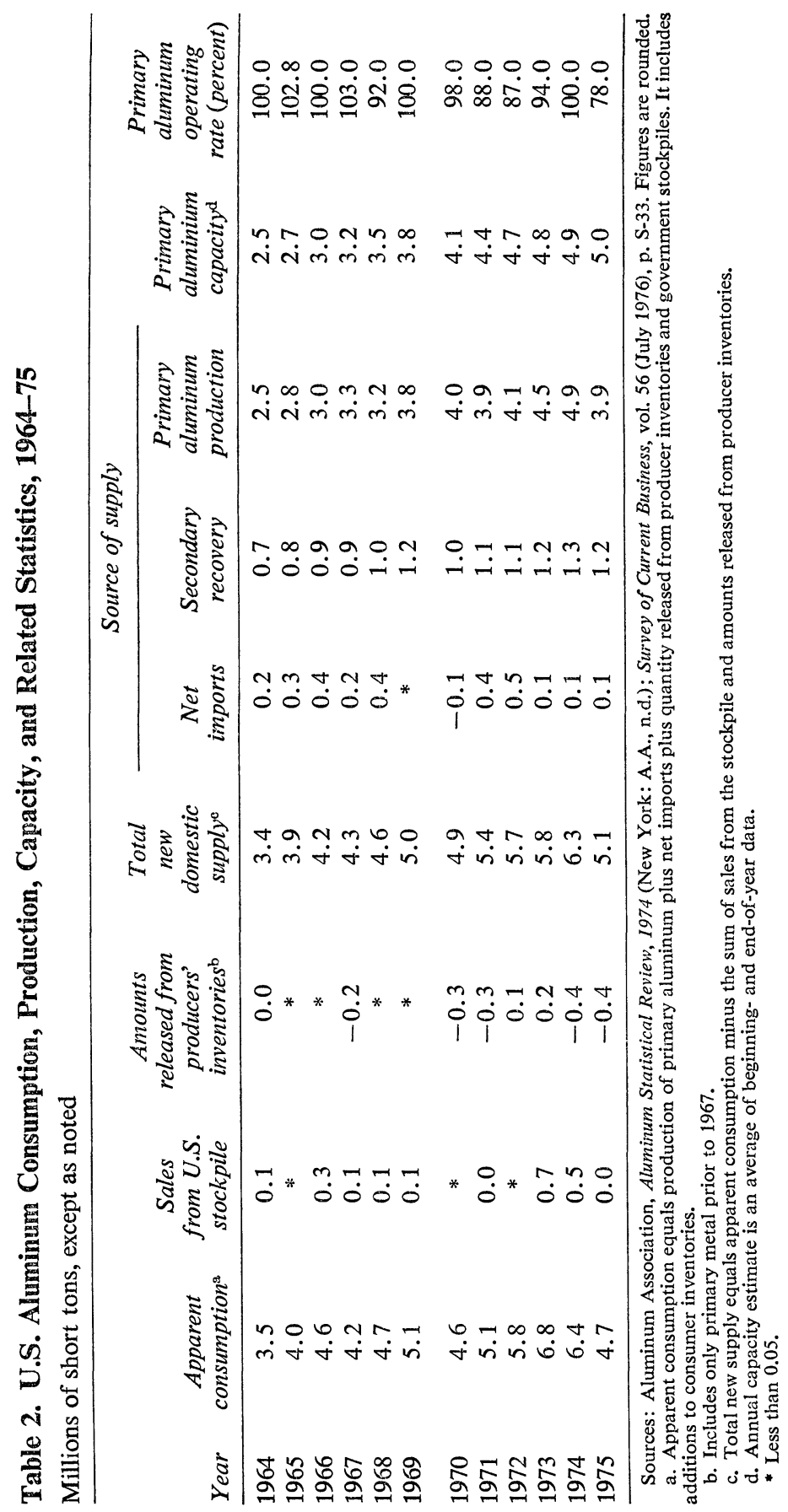


mand-equal to 18 percent for 1973 consumption in the West, excluding the United States-stimulated substantial increases in foreign prices in late 1973. Price controls appear to have altered the demand and supply balance because of the peculiar structure of the world aluminum market. Unlike most other commodities, aluminum is traded primarily between producers rather than between producers and consumers. Thus, even though imported metal was not subject to controls, producers resisted importing higherpriced foreign metal, since a two-tier price structure would upset customer relations.

By the middle of 1974 the purchase of aluminum for inventory began to reverse itself; apparent consumption fell by 31 percent between 1973 and 1975. The utilization of primary smelting capacity fell from 100 percent in 1974 to 78 percent in 1975 despite extremely large accumulations of inventories by producers.

\section{PAPER}

Imbalances between productive capacity and demand also have been a recurrent problem in the paper and paperboard industry. Unlike those in steel and aluminum, however, the problems of 1973 and 1974 are not attributable to unusual increases in demand or curtailment of supply. Demand in this industry moves very closely with overall economic activity; and, except for newsprint, imports and exports are insignificant. On the supply side the industry has tended to delay making expansion plans until production approaches capacity. Because of long lead times the new capacity is not available for two to three years and increases in capacity have tended to become available during cyclical lows in demand. The historical data, for example, display no correlation between changes in paper demand and capacity on an annual basis.

Paper and paperboard was one of the first of the basic-material industries to experience pressure on capacity in 1972 and 1973 . While capacity had expanded at an annual rate of 4.4 percent in the 1965-70 period, expansion plans were greatly curtailed by the 1970 recession, and the capacity growth rate was only 2.1 percent in 1970-72. Only a highly unusual increase of 2.5 percent in "found" capacity prevented a major shortgage in $1973 .{ }^{\circ}$ Capacity

9. The industry trade association undertakes an annual survey of all existing paper machines; determines the capacity of each machine for a base product mix; and estimates the number of days that the machine can operate during the year. Normally, the industry 
Table 3. U.S. Paper and Paperboard Production and Capacity, 1960 and 1965-75

Millions of short tons, except as noted

\begin{tabular}{cccc}
\hline Year & Capacity & Production & $\begin{array}{c}\text { Utilization } \\
\text { rate (percent) }\end{array}$ \\
\hline 1960 & 40.8 & 34.4 & 84.3 \\
1965 & 47.2 & 44.1 & 93.4 \\
1966 & 49.7 & 47.1 & 94.7 \\
1967 & 52.7 & 46.9 & 89.0 \\
1968 & 55.1 & 50.7 & 92.0 \\
1969 & 57.3 & 54.0 & 94.2 \\
1970 & 58.7 & 53.3 & 91.0 \\
1971 & 59.8 & 55.1 & 92.1 \\
1972 & 61.9 & 59.4 & 96.0 \\
1973 & 64.5 & 61.3 & 95.0 \\
1974 & 66.1 & 59.9 & 90.1 \\
1975 & 67.4 & 52.3 & 77.6 \\
\hline
\end{tabular}

Sources: American Paper Institute, Statistics of Paper and Paperboard, 1975 (API, 1975), pp. 20-22; and U.S. Bureau of the Census, Industry Reports: Pulp, Paper, and Paperboard. Capacity data prior to 1972 are averages of beginning- and end-of-year estimates. Figures are rounded.

utilization in 1972 and 1973 exceeded the levels reached in any previous postwar period (see table 3).

As with steel and aluminum, a simple demand equation for paper and paperboard was estimated for the 1955-72 period and the result was used to forecast demand in 1973-75. Actual production was only slightly less than the predicted level in 1973 and was slightly above that in 1974. The 13 percent drop in 1975 was larger than anticipated by the equation; but, since production recovered sharply in late 1975 and early 1976, the decline may have been related to the very large decumulation of aggregate stocks. In comparison with steel and aluminum, there is less evidence of significant purchases beyond needs in 1974..$^{10}$

operates three shifts and seven days a week. The average number of operating days for the industry is about 348 . There is, in addition, some ability to shift the product mix on individual machines. In 1973 the industry added to capacity by increasing the number of operating days, and by reducing the range of products produced as a means of minimizing time lost in switching the product mix.

10. In estimating demand equations for all three industries, I could obtain significant effects for relative prices only in the paper industry. Relative prices did not change sharply in the years prior to 1971 , and $1971-73$ is a period of price controls. Relative prices may have significantly depressed demand in 1975, since 1974-75 was a period of major price increases. 
The industry did encounter some spot shortages of pulpwood as a result of severe weather, but these do not seem to have been of major importance nor inconsistent with an industry producing near full capacity. The growth of demand appears to have been in line with a normal cyclical recovery. Instead, the major cause of the paper shortage in 1973 was inadequate processing capacity. The slowing of capacity expansion after the 1969-70 recession is particularly marked. Even if the 1973 gain in capacity from more operating days and longer runs is included, overall capacity increased by only 15 percent in the 1969-74 period compared with 26 percent in the preceding five years. More stringent pollution-abatement controls may have affected decisions to build new capacity, but few existing plants were shut down for this reason. ${ }^{11}$ Because net imports are a minor source of supply for domestic use (except for newsprint), it seems implausible that either devaluation or the existence of controls could have had a significant effect on quantities available for domestic consumption.

\section{SUMMARY}

Clearly, 1973 was a year of intense pressures on capacity for all three of these industries. And that experience cannot be explained as one of unusual demand arising out of speculative inventory buildups. While purchases for inventories sustained the boom into 1974, the speculative demand seems to be more of a response to the 1973 pressures on capacity than a cause of them. Capacity had been growing slowly in all three industries. And the immediate problems for steel and aluminum followed from the unusually strong rise in durable-goods production during the recovery from recession. For paper, capacity was inadequate to meet even the more normal rise in demand that occurred.

In all three of these industries it is difficult to find evidence of a major influence of wage-price controls. On the supply side, the construction period for new capacity is too long for the introduction of controls in late 1971 to have significantly affected capacity in 1973. Because imports were exempt from restrictions, one would expect any diversionary impact on the trade balance to be reflected primarily in exports. But, since the drop in

11. Data are available for shutdowns of complete mills since 1965 . These show a total lost capacity of 0.8 million tons in the 1965-69 period and 1.2 million tons in 1970-74. Data are available since 1970 for machine shutdowns when the complete mill was not closed, but there is no earlier reference period. 
steel imports was far larger than the rise of exports, it is more plausible to attribute the shift of the trade balance in this industry to factors other than controls, such as the devaluation of the dollar, the inflation in other producing countries, and the strength of demand abroad. For both the aluminum and paper industries (except newsprint), imports and exports are minor items in overall supply and changes were negligible during the period of tight capacity.

\section{Investment and Capacity Growth}

Normally, increases in capital and capacity are treated as synonymous, and most discussions of the capacity problem have focused upon the need for additional investment incentives. Yet, surprisingly, in these individual industries the two concepts do not correspond closely. It has been possible to obtain accurate statistical explanations of investment at the level of individual industries. But for these three industries, investment expenditures are not a satisfactory proxy for increases in capacity..$^{12}$

As illustrated by the data of table 4, the relationship between investment and growth in capacity is highly variable. Even with five-year averages used as a means of minimizing the role of lags between investment and an increment to capacity, the two measures correspond only in the most general way.

In part, this lack of correspondence can be explained by the more discontinuous nature of changes in capacity. But, in addition, capacity growth can be accomplished by a wide range of measures, whose investment costs also vary widely; and a large proportion of investment may be directed at modernization, pollution abatement, and replacement rather than expansion. In the case of steel, for example, estimates indicate a more rapid growth of both capital stock and investment during the 1960s than during the 1950 s. Yet, capacity expanded by nearly 50 percent between 1950 and

12. Examples of investment equations for individual industries are provided by Bert G. Hickman, Investment Demand and U.S. Economic Growth (Brookings Institution, 1965), and Dale W. Jorgenson and James A. Stephenson, "The Time Structure of Investment Behavior in United States Manufacturing, 1947-1960," Review of Economics and Statistics, vol. 49 (February 1967), pp. 16-27. The investment series used in this study are based upon establishment data from U.S. Bureau of the Census, Annual Survey of Manufactures, various issues. Thus, they do not include investment in other industries by diversified firms, as is the case with the more common company-based data. 
Table 4. Investment and Capacity Growth in the Steel, Aluminum, and Paper Industries, Five-Year Periods, 1956-75

Billions of 1972 dollars and millions of tons

\begin{tabular}{|c|c|c|c|c|c|c|}
\hline \multirow[b]{2}{*}{ Period } & \multicolumn{2}{|c|}{ Steel } & \multicolumn{2}{|c|}{ Aluminum } & \multicolumn{2}{|c|}{ Paper and paperboard } \\
\hline & $\begin{array}{l}\text { Investment } \\
\quad(\text { dollars })\end{array}$ & $\begin{array}{c}\text { Change in } \\
\text { capacity } \\
\text { (tons) }\end{array}$ & $\begin{array}{l}\text { Investment } \\
\text { (dollars) }\end{array}$ & $\begin{array}{c}\text { Change in } \\
\text { capacity } \\
\text { (tons) }\end{array}$ & $\begin{array}{l}\text { Investment } \\
\text { (dollars) }\end{array}$ & $\begin{array}{c}\text { Change in } \\
\text { capacity } \\
\text { (tons) }\end{array}$ \\
\hline $1956-60$ & 7.5 & 21.9 & 0.6 & 0.8 & 3.1 & 8.2 \\
\hline $1961-65$ & 7.0 & 3.7 & 0.3 & 0.3 & 3.4 & 6.7 \\
\hline $1966-70$ & 9.7 & 2.8 & 0.7 & 1.5 & 4.8 & 10.9 \\
\hline $1971-75$ & 6.5 & 1.0 & 0.6 & 0.8 & 3.5 & 9.9 \\
\hline
\end{tabular}

Sources: The data on capacity are from tables 1,2 , and 3 , or the sources given there. The investment data are from U.S. Bureau of the Census, Annual Survey of Manufactures, 1973 (1975), and previous issues. Data for 1974-75 are derived by the author from the historical relationship of the establishment data of the Annual Survey and various sources of company-based data. The investment series for steel and paper exclude estimated outlays for pollution abatement.

1960 and by less than 5 percent in the subsequent decade. Finally, some growth in capacity can result from "learning-by-doing": increasing the capacity of existing machines through better scheduling and better maintenance-which do not require investment.

Since 1960 the steel industry has made major investments in basic-oxygen and electric-steel furnaces. Yet, these expenditures added almost nothing to capacity on balance as the older open-hearth furnaces were torn down. They were not kept for standby capacity because the raw-materials and finishing-mill capacity to handle a temporary surge of output does not exist. In such process-related industries, duplicative capacity at only one production stage is of limited value. Moreover, even if these obstacles could be overcome, the cost of equipping the older furnaces to meet pollutionabatement regulations would be prohibitive for temporary operation.

Even in the case of the aluminum industry, however, in which there have been few technological changes and increases in capacity take the form of additional reduction units to produce aluminum from alumina, investment in the previous three years explains less than half of the annual change in capacity. In this industry, problems in the investment data may account, in part, for the low correlation. The Annual Survey of Manufactures attempts to include investment at plants not yet in operation by a special survey questionnaire to companies. The coverage of the survey is not as complete as that for operating plants, and it probably does not fully capture investment by new companies. In the aluminum industry new plants have been a major form of capacity expansion and the number of firms has 
grown from three in 1954 to twelve in 1975. These new firms accounted for 52 percent of the growth in capacity, but it is doubtful that all of their investment is included in the survey of expenditures.

The paper and paperboard industry provides some of the most detailed data on capacity changes and thus an opportunity to examine closely the relationship between capital and capacity. Every year, the American Paper Institute questions all establishments about total capacity at the end of the previous year. In addition, firms report all projected increases in capacity, divided into new machines and net improvements, based upon expenditure commitments over the subsequent three years. Net improvements include shutdowns of existing machines, gains or losses from rescheduling of the mix of products, and modifications to increase the output of machines that have been in place for more than two years. The actual change in capacity is not divided between new machines and net improvements; but, since the one-year forecast errors of the survey normally have been very small, the forecast of new machine capacity should be a close approximation to the actual. Over 80 percent of the woodpulp is produced at the same location, so that the investment data include expenditures for associated pulping facilities. Finally, pollution-abatement expenditures have averaged about 30 percent of total investment since 1970. An estimate of these expenditures was deducted from the total and the result deflated to 1972 constant dollars by a weighted average of the national income account deflators for structures and equipment.

A positive relationship between capacity changes and investment was found only for the new-machines component:

$$
\begin{aligned}
N M C & =\underset{(1.2)}{-3.79}+\underset{(0.4)}{0.17} I+\underset{(3.5)}{1.85} I_{-1}, \\
R^{2} & =0.65 ; \text { standard error }=0.351 .
\end{aligned}
$$

where $N M C$ equals new machine capacity in thousands of annual tons and $I$ equals investment in millions of 1972 dollars. The numbers in parentheses are $t$-statistics. Although there is considerable unexplained variance, some of the individual residuals seem to reflect a variable lag between investment and measured changes in capacity. The estimated capital cost from the equation of $\$ 495$ (1972 prices) per ton of annual capacity seems to agree closely with industry estimates of the costs of new plants. The importance of lagged investment in the equation indicates, on average, that this lag is fairly long. 
On the other hand, a similar equation for the total change in capacity, including net improvements as well as new machines, yields an $R^{2}$ of less than 0.3 . The adjustment of the capacity estimates for mill closures since 1965 had no influence on the results. The relationship for overall capacity changes deteriorated because capacity changes other than those from new machines have no apparent link to investment. Yet, these net improvements (including losses due to plant closures) have accounted for nearly 40 percent of the growth in capacity between 1958 and 1975. Many of these changes within the paper industry have revolved around modifications that enabled existing machines to operate at higher speed and with less downtime for repairs.

In effect, the net change in an industry's capacity is derived from several components, including construction of new plants, expansion of existing plants and technological innovations in them, and plant shutdowns. As a result, the capital cost of a net increment to capacity varies considerably over time. Furthermore, only part of any year's investment is directed toward expanding capacity. The relationship between total investment and the net change in capacity, thus, is likely to be highly erratic, and the changes in the former may be a poor indicator of the latter.

\section{Sources of Change in Supply Costs}

Although the investment associated with a given change in capacity may be highly variable over time, expansion of capacity will still be motivated by economic incentives. These incentives revolve around the answers to two questions: (1) What level of market prices would be required to make new plant capacity profitable? (2) Do forecasts of industry demand relative to existing capacity imply that such prices will be forthcoming?

Prices have increased sharply in the three industries considered here, despite the recession-induced decline in demand. Between December 1973 and June 1976, steel-mill prices rose by 55 percent; aluminum ingot, 49 percent; and paper and paperboard, 46 percent. The magnitude of these increases seems to offer strong inducement to expand capacity. Yet, these industries also have experienced major cost increases for raw materials and labor; they are energy-intensive industries strongly affected by the higher fuel prices; and higher equipment prices and more stringent pollutionabatement standards have sharply raised the capital costs for new plants. 
Price increases thus may not have been sufficient to create positive incentives for new supply.

Reported profits within the industry may be equally difficult to interpret as a measure of expansion incentives, particularly during periods of rapid inflation. They reflect the lower, historical capital costs of existing plants, and, in many cases, raw materials contracted for at prices substantially different from the market levels relevant for new plants. Also, the economic effects of pollution-abatement regulations are not the same for new plants as for existing ones. For the latter, the dominant portion of the capital expenditures have already been made, and the firm confronts the need to make an incremental capital expenditure to comply with the new requirements or lose its prior investment. But, for a new plant, the pollutionabatement costs are equivalent to an increase in the price for capital equipment and the whole project can be canceled or postponed if it is not profitable.

The analysis of costs and prices in this paper abstracts from risk and implicitly assumes that expected profitability will govern decisions about expansion. While this analysis should reveal the basic expansion prospects for these industries, the financing of expansion projects poses two additional issues for investment prospects that should be noted. First, because capital-goods costs have risen, fixed contractual interest payments on new facilities will be higher than they are on existing plants with the same operating costs. Even though rational calculations will disregard this, for some firms this invidious comparison between the fixed interest cost of new and existing facilities may inhibit investment. Second, the higher nominal interest rates that accompany today's expected inflation raise the fixed costs that have to be paid even if the inflation rate slows. This makes a project financed today somewhat riskier than one financed in less inflationary times.

Measures of the supply costs relevant for new capacity can be constructed. Recent efforts by the Environmental Protection Agency to measure the economic effects of pollution-abatement regulations have produced a series of detailed studies of several basic-material industries, several of which have been based upon detailed cost models of individual processes within the industry. By combining these process requirements with available information on material prices, wage rates, and capital-goods prices it is possible to construct a detailed cost structure for a new plant that produces a specified mix of outputs. The methods used to construct these cost structures for the steel, aluminum, and paper industries are outlined in the fol- 
lowing section of this paper. Second, these cost models can be linked to price indexes for materials, labor, and capital goods to construct an index that depicts how supply costs have changed over time. Thus, it is possible to examine the implications for product prices of recent large increases in a wide range of costs such as those for raw materials, fuels, pollution abatement, and capital goods. Third, movements in the overall supply costs (inclusive of both variable and fixed costs) can be matched against output prices as a means of determining incentives to expand capacity.

\section{THE COST STRUCTURE}

For each of these three industries the specific method of constructing the supply cost varies slightly because of differences in the nature of the basic data. However, the general approach involves translating the product mix in a base year into production requirements for each process. Input requirements for each process were combined with input prices to develop a detailed bill of input costs per unit of output for an optimal-size plant operating at a preferred utilization rate.

In order to allocate capital charges (depreciation plus return to capital) to annual production, the neoclassical concept of a rental price of capital has been used in these calculations. The empirical formulation corresponds to that used by Jorgenson and others in investment studies, except that for pricing purposes economic depreciation is taken to be straight-line over the life of the capital rather than the perpetual-inventory method of most investment models. ${ }^{13}$ The specific formula for the rental price is

$$
P_{k}^{s}=\frac{P_{k}(r+d)(1-\rho z-t)}{(1-\rho)},
$$

where

$$
\begin{aligned}
& P_{k}^{s}=\text { the rental (or service) price of capital } \\
& P_{k}=\text { the price of capital goods }
\end{aligned}
$$

13. See, for example, Robert E. Hall and Dale W. Jorgenson, "Application of the Theory of Optimum Capital Accumulation," in Gary Fromm, ed., Tax Incentives and Capital Spending (Brookings Institution, 1971). Use of a perpetual-inventory concept of depreciation would imply a falling price relative to direct costs over the life of the plant. Separate estimates made of the price of equipment and structures were the same for all three industries and were weighted by the proportion of structures and equipment appropriate to each industry. Useful lives are fourteen years for equipment and thirty-four years for structures. All other parameters of the rental-price term except depreciation and the cost of capital are from the data bank of the Federal Reserve Board model. 
$r=$ the cost of capital

$d=$ the depreciation rate

$\rho=$ the corporate tax rate

$z=$ the present value of the depreciation allowance

$t=$ the rate of the investment tax credit.

Thus, bigger investment tax credits, more liberal depreciation allowances, and lower taxes all have the effect of reducing the rental price of capital on an after-tax basis.

The choice of a measure for the cost of capital plays a critical role in allocating capital costs since different measures show sharply different trends. Clearly, the nominal rate of interest is not appropriate when future inflation of prices can be anticipated. In a previous paper in this journal, William Nordhaus developed an empirical measure of the cost of capital based on a weighted average of the real return on bonds and the return on stock. ${ }^{14}$ However, an attempt to extend his measure through 1975 led to implausible results since an autoregressive weighting of inflation rates to estimate expected inflation, which he had used, gave extremely low estimates of the cost of capital in the 1973-75 period of high inflation. Also, his correction of the return on stock for capital gains yields an extremely volatile measure during this period. The use of this measure of the cost of capital would have swamped the influence of other cost changes on the supply cost.

Rather than an annual measure of the cost of capital, the cost estimates reported in this paper are based on a constant 6 percent after-tax rate of return, which is close to the average of Nordhaus' estimate over the last twenty years. In a later section of the paper, the significance of alternative measures will be examined.

The estimated structures of costs for the three industries are shown in tables 5, 6, and 7. Conceptually, these cost data vary among the industries and should be interpreted with some caution. First, for the purposes of this study, cost data for a new, modern plant would be most desirable; but such information was available only for the paper and paperboard industry. The costs for the steel and aluminum-ingot industries are based on the average experience of existing plants. Second, an attempt is made to include raw-material costs at the market level relevant for new plants rather than the transfer price for firms that may have developed their own sources of

14. William D. Nordhaus, “The Falling Share of Profits,” BPEA, 1:1974, pp. 169-208. 
Table 5. Costs of Production in the Steel Industry, by Component

\begin{tabular}{lcc}
\hline Cost component & $\begin{array}{c}\text { Cost per ton } \\
\text { of output } \\
(1972 \text { dollars })\end{array}$ & $\begin{array}{c}\text { Percentage of } \\
\text { supply cost }\end{array}$ \\
\hline Operating & & \\
Raw materials & 56.89 & 22.9 \\
Ore & 25.54 & 10.3 \\
Coal & 12.12 & 4.9 \\
Scrap (net) & 11.12 & 4.5 \\
Other raw materials (net) & 8.11 & 3.3 \\
Power and fuel (net) & 7.09 & 2.9 \\
Direct labor & 33.25 & 13.4 \\
Overhead labor & 37.79 & 15.2 \\
Maintenance and & & \\
$\quad$ miscellaneous materials & 30.43 & 12.2 \\
Sales and property taxes & 11.01 & 4.4 \\
Pollution abatement & 8.85 & 3.6 \\
$\quad$ Subtotal & 185.31 & 74.6 \\
Fixed capital & & \\
Plant & 52.33 & 21.1 \\
Pollution abatement & 7.05 & 2.8 \\
$\quad$ Subtotal & 59.38 & 23.9 \\
Working capital & 3.69 & 1.5 \\
$\quad$ Total supply cost & 248.38 & \\
\hline
\end{tabular}

Source: Calculated by author from sources described in text. Figures are rounded.

a. Environmental operating and capital costs are those for a new plant that is constructed to meet 1983 standards and thus they overstate actual industry costs. Actual environmental operating costs are estimated at $\$ 2.30$ per ton in 1972 .

b. Capital costs per ton are estimated at $\$ 375$ for plant and $\$ 86$ for pollution abatement. The annualized costs in the table are based on a 6 percent after-tax rate of return, using the formula for the rental price of capital discussed in the text.

c. Working capital is estimated at $\$ 32$ per ton and the annualized cost is $32 r /(1-t)$, where $r$ is the cost of capital and $t$ is the tax rate.

raw materials or have long-term contracts. In addition, costs for individual plants within the industry may vary because of location and product mix. The cost data are of primary value as a source of base-period weights for the construction of the time-series indexes of total costs in the following sections.

Steel. The cost structure for the steel industry, detailed in table 5, was derived from a report by Temple, Barker, and Sloane, Inc., for the Environmental Protection Agency. ${ }^{15}$ This study provided detailed input require-

15. U.S. Environmental Protection Agency, Economic Analysis of Proposed and Interim Final Effluent Guidelines: Integrated Iron and Steel Industry (EPA, Office of Planning and Evaluation, 1976). This study, in turn, drew heavily upon process data developed by Arthur D. Little, Inc., for a report to the American Iron and Steel Institute. The staff of Temple, Barker, and Sloane provided additional detail for the 1972 estimates. 
Table 6. Costs of Production in the Primary Aluminum Industry, by Component

\begin{tabular}{lcc}
\hline Cost component & $\begin{array}{c}\text { Cost per ton } \\
\text { of output } \\
\text { (1972 dollars) }\end{array}$ & $\begin{array}{c}\text { Percentage of } \\
\text { supply cost }\end{array}$ \\
\hline Operating & & \\
Alumina (1.93 tons) & 126.60 & 25.1 \\
Carbon anodes (0.5 ton) & 26.10 & 5.2 \\
Other materials & 7.6 \\
Power (13 kwh) & 38.45 & 11.5 \\
Labor & 58.25 & 17.9 \\
Production & 90.60 & 13.3 \\
Overhead & 67.20 & 4.6 \\
Miscellaneous costs and taxes & 23.40 & 5.0 \\
Pollution abatement & 25.00 & 0.0 \\
$\quad$ Subtotal & 0.0 & 72.3 \\
Fixed capital & 365.00 & \\
Plant & & 24.4 \\
Pollution abatement & 123.00 & 2.1 \\
$\quad$ Subtotal & 10.37 & 26.4 \\
Working capital $^{\mathrm{b}}$ & 133.37 & 1.3 \\
$\quad$ Total supply cost & 6.46 & 100.0 \\
\hline
\end{tabular}

Source: Calculated by author from sources given in text. Figures are rounded.

a. Primarily fluoride compounds.

b. Estimates of the cost of emission control of fluorides are taken from U.S. Environmental Protection Agency, Office of Air Quality Planning and Standards, Background Information for Standards of Performance: Primary Aluminum Industry, vol. 1 (Research Triangle Park, North Carolina: EPA, 1974), pp. 48-49. Credits for recovery of alumina and fluoride offset other operating costs.

c. Capital costs per ton of annual production are derived from EPA study cited in note $b$ and the U.N. study cited in text note 17 . They are $\$ 900$ for plant; $\$ 72$ for the environment; and $\$ 56$ for working capital. The costs are based on a 6 percent after-tax cost of capital using the formula for the rental price of capital described in the text.

ments and outputs for twenty-eight basic processes within the steel industry based upon 1972 operating data of the members of the American Iron and Steel Institute. Thus, the cost estimates are based on average operating patterns in 1972 rather than an engineering model of an integrated new plant. The processes that were separately identified included raw-material handling yards, coke ovens and blast furnaces, three steel-making processes, casting and forming, and eleven steel-finishing processes. The 1972 mix of steel shipments was allocated to these processes by a productionrequirements matrix. Costs for each process were then measured and summed over all the processes. Where appropriate, credits for energy, scrap, and other raw-materials recovery were applied to the gross input needs. Thus, while the industry uses 0.73 ton of scrap per ton of steel shipments, over half of it is generated as an output of other processes. 
Table 7. Costs of Production in the Paper and Paperboard Industry, by Component

\begin{tabular}{lcc}
\hline \multicolumn{1}{c}{ Cost component } & $\begin{array}{c}\text { Cost per ton } \\
\text { of output } \\
(1972 \text { dollars })\end{array}$ & $\begin{array}{c}\text { Percentage of } \\
\text { supply cost }\end{array}$ \\
\hline Operating & & \\
$\quad$ Fiber & 34.46 & 15.8 \\
Other raw materials & 32.38 & 14.8 \\
Direct labor & 17.67 & 8.1 \\
Energy & 8.39 & 3.8 \\
Overhead & 19.52 & 8.9 \\
Environmental and OSHA & & \\
$\quad$ operating costs & & 2.0 \\
General sales and administration & 21.82 & 10.0 \\
$\quad$ Subtotal & & 63.4 \\
Fixed capital & & \\
Plant & 138.60 & 29.5 \\
OSHA & & 0.7 \\
Pollution abatement & & 4.2 \\
$\quad$ Subtotal & 64.55 & 34.5 \\
Working capital $^{\mathrm{d}}$ & 1.61 & 2.1 \\
$\quad$ Total supply cost & 9.24 & 100.0 \\
\hline
\end{tabular}

\footnotetext{
Source: Calculated by author from sources described in text.

a. OSHA costs are estimated outlays required to meet the standards of the Occupational Safety and Health Act. The estimates of pollution abatement incorporate costs of meeting the (1) best practical technology by 1977 ; (2) best available technology economically achievable by 1983 ; (3) and new-source performance standards. Because of the focus upon costs for new capacity, the new-source performance standards are most relevant.

b. The cost estimates exclude delivery charges in order to conform to the conceptual basis of the wholesale price index.

c. Capital costs per ton of annual production are estimated from the EPA report cited in text note 19 in 1972 dollars, at $\$ 443$ for plant; $\$ 12$ for OSHA; and $\$ 63$ for pollution abatement. The annualized costs in the table are based upon a 6 percent after-tax cost of capital, using the formula for the rental price of capital described in the text.

d. Working capital is estimated at $\$ 53$ per annual ton and the annualized cost is $53 r /(t-1)$, where $r$ equals the cost of capital and $t$ is the tax rate.
}

The estimated capital cost per ton of $\$ 375$ (1972 dollars) was obtained from the data of the Bureau of Labor Statistics on the gross capital stock in the steel industry. This estimate is considerably less than the estimates of $\$ 600$ to $\$ 700$ per ton discussed in recent studies of the industry's future capital needs. ${ }^{16}$ However, these higher estimates of capital costs appear to reflect a more modern plant than the industry average, with a considerable substitution of capital for labor and energy. Also, it is doubtful that these engineering estimates make adequate allowance for future capacity increases from the new plants once they are in operation, or for unforeseen

16. See, for example, Paul Marshal, "Summary [of a steel symposium]" (paper prepared for the Council on Wage and Price Stability, 1976; processed). 
technological improvements applicable to existing plants. Such phenomena were important sources of increasing capacity ratings for the oxygen furnaces installed in the 1960s.

Aluminum. A study of the current cost structure of the aluminum industry was not available. Thus, an estimate of the average costs in the primary aluminum industry was constructed from the 1972 Census of Manufactures, a 1966 United Nations study, and various materials from the U.S. Bureau of Mines. ${ }^{17}$ This industry produces aluminum ingot by electrolytic reduction of alumina and ships the product to aluminum fabricators. One major difficulty in constructing a measure of costs is that few of the inputs are priced in open markets, and actual transaction prices may depart substantially from the list price for ingot.

The allocation of costs by category is shown in table 6. Alumina, produced from bauxite, is the major item of operating cost; but the industry also uses electric power heavily. Labor costs are relatively lower than they are for steel, and capital costs as a percent of total costs are comparable with those in the other industries. The capital costs per ton are derived from the United Nations study of the early 1960s but also coincide with those given in a study of pollution abatement by the EPA. ${ }^{18}$ The pollution-abatement costs are primarily for the restriction of fluoride emissions, and credits for recovered materials approximately equal operating costs.

Paper and Paperboard. The basic data on the structure of costs in the paper and paperboard industry are derived from a study by Arthur D. Little, Inc., for the Environmental Protection Agency. ${ }^{19}$ Most of the output of the industry is provided by mills that are integrated with a pulping facility. Woodpulp is produced primarily by three major technologies ap-

17. U.S. Bureau of the Census, 1972 Census of Manufactures, Industry Series: Smelting and Refining of Nonferrous Metals and Alloys, MC72(2)-33C (1975); United Nations, Department of Economic and Social Affairs, Pre-investment Data for the Aluminum Industry, ST/CID/9 (U.N., 1966); and U.S. Department of the Interior, Bureau of Mines, Minerals Yearbook, 1972, vol. 1 (1974).

18. U.S. Environmental Protection Agency, Office of Air Quality Planning and Standards, Background Information for Standards of Performance: Primary Aluminum Industry, vol. 1 (Research Triangle Park, North Carolina: EPA, 1974), pp. 41-93.

19. U.S. Environmental Protection Agency, Office of Planning and Evaluation, Economic Analysis of Proposed and Interim Final Effluent Guidelines for the Bleached Kraft, Groundwood, Sulfite, Soda, Deinked and Non-Integrated Paper Sectors of the Pulp and Paper Industry (EPA, 1976). Other plant models for the paperboard sector were supplied by Arthur D. Little, Inc. The cost estimates were originally shown for 1975 prices, but have been converted to 1972 prices to make them comparable with steel and aluminum costs. 
plied to pulpwood and woodchips: a high-yield mechanical process that yields groundwood, a low-grade pulp for such uses as newsprint; a chemical process that yields kraft, a high-quality pulp used for both paper and paperboard (accounting for about two-thirds of all pulp capacity); and a neutral sulfite semichemical process that produces sulfite pulp. In addition, wastepaper provides about 20 percent of the raw material-primarily for newsprint, tissue, and paperboard.

Basically, the machines that produce paper and paperboard have changed little: they have simply gotten bigger and faster. Different products can, to some extent, be produced on the same machine, but typically each is used to produce a narrow range of products.

For purposes of representing the industry, eleven integrated paper-paperboard-pulp processes were combined, weighted according to the distribution of 1973 production. Newsprint from Canada accounts for about 70 percent of the domestic market, but in other product lines imports average less than 2 percent of supply and exports are about 6 percent of production. Net imports of woodpulp represent less than 2 percent of the fiber supply. Thus, the costs of domestic production closely represent those for the total market.

The implied cost structure (in 1972 prices) for a typical ton of output is shown in table 7. Fiber costs-pulpwood, chips, and wastepaper-are the largest single component of direct costs but the industry is also a large consumer of energy. The other principal costs for raw materials cover chemicals for making both pulp and paper. The industry is also very capitalintensive: the gross return (depreciation plus a 6 percent after-tax return) to fixed capital accounts for 34 percent of total costs. Finally, the industry is sharply affected by environmental regulations, which contribute an estimated 5.7 percent to the average price..$^{20}$ These costs consist primarily of capital costs for abatement of water effluents.

Summary. The costs for all three of these industries are dominated by materials, energy, and capital; labor costs are small relative to the rest of manufacturing. Labor costs are also only a small element of the cost of the materials that they purchase. These industries are also sharply affected by the recent introduction of environmental controls, which appear to have the greatest impact on capital rather than operating costs.

20. The pollution-abatement costs are for new-source performance and are thus not the same as the current costs for existing mills. They are, however, the costs that must be anticipated for new mills. 


\section{SUPPLY-COST INDEXES}

The cost structures shown in tables 5,6 , and 7 provide a set of baseperiod weights for each element of cost in each industry; these can be used to combine price indexes on individual cost items into an overall measure of the costs of producing a standard product mix at various points in time. Since this paper focuses on the question of incentives for expanding capacity, the relevant cost measure is total costs including overhead and capital costs as well as operating costs.

Operating Costs. For most of the items included in operating costs, historical measures of price change are available from the wholesale price index. In a few cases, such as pulpwood for the paper industry or alumina for aluminum-ingot production, additional price indexes were derived from publications of the Department of Agriculture and the Bureau of Mines. Supplementary information on specific material inputs and different fuel requirements were obtained from the 1972 Census of Manufactures. The nonfarm business deflator of the national income accounts was used for materials and supplies that could not be separately identified or for which price indexes were not available. An index of rail freight rates, compiled by the Department of Labor, was used to impute transportation costs when they were not included in the basic price index.

Changes in labor costs were measured by constructing an index of unit labor costs for each industry at a standardized level of the capacity-utilization rate. Wage rates were measured by adjusting payroll data of the Department of Labor by the ratio of employee compensation (including fringes) to wages for the private nonfarm economy. The indexes of labor productivity, published by the Bureau of Labor Statistics, were adjusted to eliminate the influence of cyclical departures from preferred operating rates by regressing the index on the industry operating rate and a time trend, and using the estimated coefficient on the utilization rate to adjust the measured productivity to a constant utilization rate.

The combination of these indexes for labor, materials, and fuels provides a measure of the change in variable or operating costs. The contributions of the major components in the 1972-75 period are shown in table 8 . Clearly, costs in these industries have risen at an extremely high rate compared with the rest of the economy. While the prices in the nonfarm sector went up by 26.4 percent during the period, increases in operating costs for 
Table 8. Sources of Change in Operating Costs for the Steel, Aluminum, and Paper Industries, 1972-75

\begin{tabular}{cccc}
\hline $\begin{array}{c}\text { Cost } \\
\text { component }\end{array}$ & Steel $^{\mathrm{a}}$ & Aluminum & $\begin{array}{c}\text { Paper } \\
\text { and paperboard }\end{array}$ \\
\hline Materials & Percentage change in cost component & \\
Energy & 63.4 & 76.8 & 43.7 \\
Labor & 154.9 & 69.2 & 112.4 \\
Other & 31.1 & 37.7 & 18.0 \\
Total & 26.4 & 26.4 & 22.6 \\
& 50.5 & 62.5 & 37.4 \\
Materials & Percentage contribution to total change $^{\mathrm{c}}$ & \\
Energy & 30.4 & 65.3 & 56.5 \\
Labor & 31.8 & 16.8 & 18.2 \\
Other & 23.6 & 15.0 & 9.2 \\
Total & 14.2 & 2.9 & 16.1 \\
& 100.0 & 100.0 & 100.0 \\
\hline
\end{tabular}

Sources: Author's calculations as described in the text, and the distribution of costs shown in tables 5, 6 , and 7.

a. Coal costs for the steel industry are included as part of the energy component because of the common factors affecting recent price changes.

b. Labor costs include both direct and overhead labor.

c. The percentage contribution is equal to the dollar change in the specific cost component as a percent of the dollar change in total operating costs.

these industries ranged from 62.5 percent (aluminum) through 50.5 percent (steel) to 37.4 percent (paper and paperboard). The major reason for this difference is that value-added prices in the economy as a whole are dominated by labor costs while these industries are affected more by costs of energy and raw materials.

In the 1972-75 period, the aluminum industry experienced the largest increase in operating costs under the impact of actions by two cartels, the Organization of Petroleum Exporting Countries and the International Bauxite Association. The United States depends heavily upon imported bauxite, primarily from Jamaica. The Jamaican government raised the tax on bauxite from about $\$ 2.50$ to $\$ 11.72$ per ton in May 1974 and tied future taxes to 7.5 percent of the list price of aluminum in the United States. This rate was scheduled to be moved up to 8 percent in early 1975 and 8.5 in 1976, although its application varies among the companies. Thus, for example, at a price of $40 \phi$ per pound for aluminum in the United States, the levy in 1975 would be about $\$ 15$ per ton of bauxite. ${ }^{21}$ This tax increase was reflected in a doubling of bauxite prices per ton, as reported by the com-

21. Calculated at $.08[.40(2000)] / 4.3$. The factor of 4.3 is used to convert aluminum into the equivalent amount of bauxite. 
panies, from $\$ 14.84$ in 1973 to $\$ 29.85$ in 1975 . Since it takes about two tons of bauxite to yield one ton of alumina, this tax alone accounts for the major share of the rise in reported alumina prices from $\$ 65.60$ per ton in 1972 to $\$ 116.35$ in 1975 . In addition, the costs of other materials increased sharply.

The increases in energy costs in the aluminum industry were less dramatic than they were for steel or paper. The industry relies heavily upon electric power, for which fuels represent only about one-half of costs. Finally, unit labor costs rose 38 percent as a result of low growth in productivity and very large increases in wage rates in recent years.

Higher energy prices had the greatest impact on the steel industry because of the importance of coking coal, whose price rose as a reflection of its alternate use as a fuel. Iron ore and scrap prices also shot up during the period. Increases in wage rates in steel were comparable with those in aluminum, but the industry had a higher rate of growth in productivity.

Operating-cost increases were less dramatic in the paper and paperboard industry than in steel and aluminum, but still considerably exceeded those in the rest of the economy. Again, the major cost increases resulted from higher material and energy costs, as labor costs were held down by a particularly rapid growth of productivity. Higher pulpwood prices seem to reflect a growing shortage of forest land and reduced lumber production during the period, which lowered the available supply of wood chips. Furthermore, chemical costs roughly doubled.

Total Costs. While operating costs are most relevant to the pricing and output decisions of an existing plant, a measure of the supply cost relevant to new capacity requires the addition of capital costs. Since the basic calculations of this paper reflect a constant 6 percent after-tax cost of capital, the capital-cost component of the supply-cost index reflects changes only in the prices of capital goods and in tax rates. The price of capital goods for all three industries is simply a weighted average of the deflator for equipment and structures of the national income accounts.

The resulting measure of supply cost has serious limitations because of the treatment of technological change. Such changes are included only to the extent that they lower labor requirements. Improvements in labor productivity are assumed to result from factors other than capital-labor substitution since the capital-cost estimates are not raised in an offsetting fashion. ${ }^{22}$ These three industries are not among those that have experienced

22. For each of the three industries considered in this study the capital-output ratio shows no appreciable trend in the Department of Commerce study of fixed-capital re- 
major technological changes during the last decade, but the supply-cost indexes may become increasingly inaccurate measures of the costs for a new plant when applied over long spans of time.

If any ability to alter production techniques exists, the assumption of a fixed technology clearly will tend to overstate cost increases in years following the base period. The direction of bias in the index for years prior to the base period, however, is indeterminate. The base-period technology, even if known, may not have been optimal in earlier years, with a different relative-price structure for inputs. On the other hand, the index may reflect newly discovered production techniques that would dominate older methods of production at any relative-price structure.

Ideally, the index should be constructed with weights reflecting the optimal cost structure in each year. Although this cannot be done, it appears that technological change has been relatively modest in these three industries, and that the adjustment of labor inputs captures its major influence. In addition, this study is concerned primarily with changes in the index over relatively short periods. The indexes are constructed for the decade of the 1960s chiefly as a check of their reasonableness in an analysis of cost changes during the 1970s. The prices of some materials have increased dramatically, but others have not. The supply-cost indexes are intended to provide a measure of the overall change in costs.

Finally, beginning in 1972, the supply-cost indexes include the full costs for a new plant that meets the 1983 pollution-abatement standards. While this inclusion might be reasonable for capital costs, it overstates the actual operating costs incurred. In addition, it introduces an artificial discontinuity in the cost indexes.

Steel. The index of the historical supply cost for steel is shown in table 9. Costs for individual materials were extrapolated with wholesale price indexes, and labor costs were estimated by adjusting the Bureau of Labor Statistics productivity index for cyclical fluctuations and combining it with data on employment costs from the American Iron and Steel Institute (AISI). ${ }^{23}$ The market price was estimated by benchmarking the wholesale

quirements; see U.S. Department of Commerce, Bureau of Economic Analysis, A Study of Fixed Capital Requirements of the U.S. Business Economy, 1971-1980 (1975; distributed by National Technical Information Service), pp. 22-51. For a discussion of the complex issues involved in measuring input productivity, see Edward F. Denison, "Some Major Issues in Productivity Analysis: An Examination of Estimates by Jorgenson and Griliches," Survey of Current Business, vol. 49 (May 1969), pt. 2, pp. 1-27.

23. Annual Statistical Report, American Iron and Steel Institute, 1974 (AISI, 1975), pp. 21-25. 


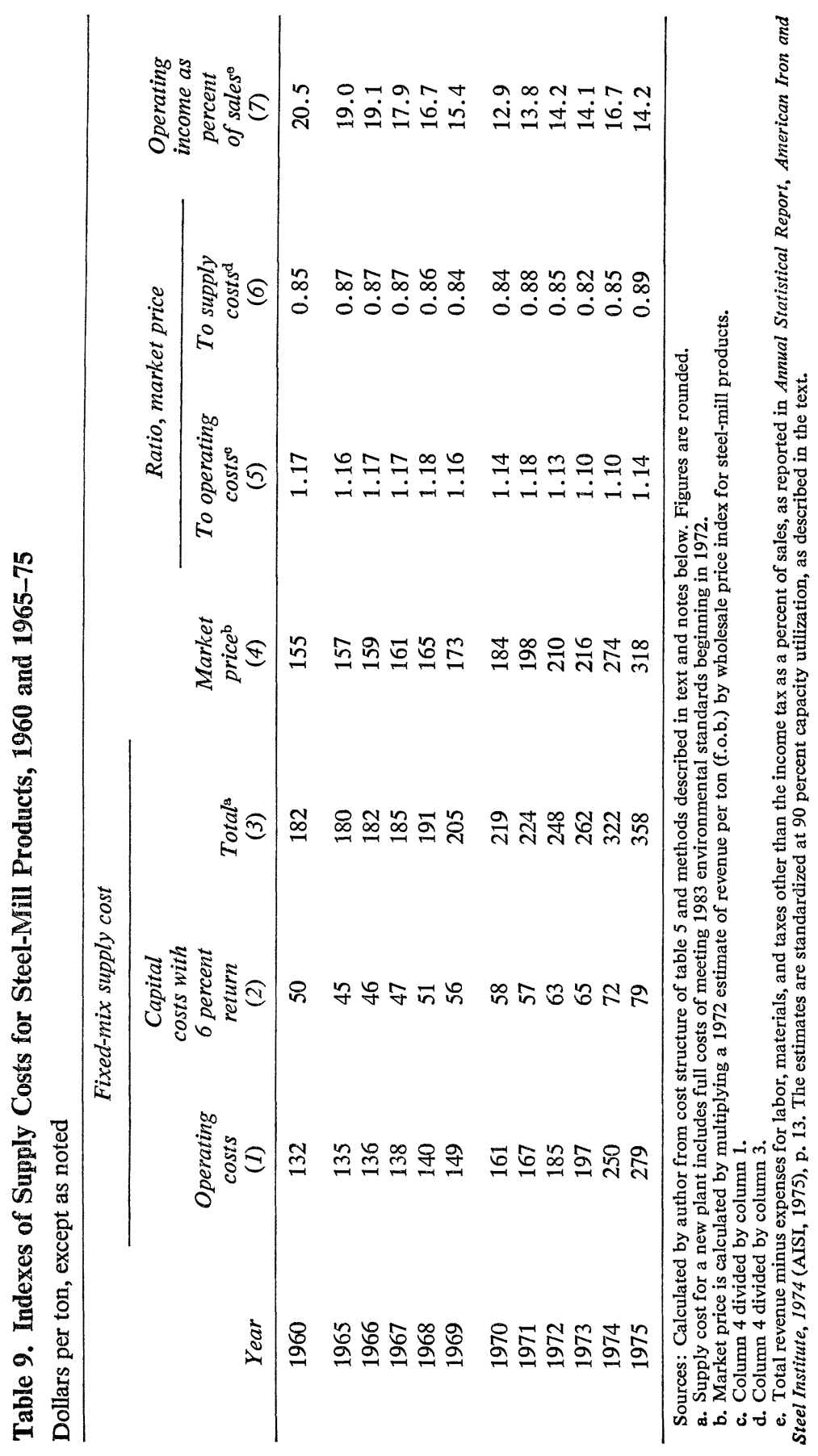


price index for steel-mill products to an estimate of revenue per ton (excluding delivery charges) of $\$ 210$ in 1972 . Because of the difficulty in computing costs on precisely the same basis as prices, the change in the index of market prices relative to costs (as shown in columns 5 and 6), rather than its absolute level, is the most relevant figure.

The index of the supply cost indicates that average costs rose only modestly throughout the 1960s. Fixed capital costs actually declined in the first half of the decade as tax reductions (such as the investment tax credit, liberalized depreciation, and a lower basic tax rate) more than offset the rise in capital-goods prices. With the assumed 6 percent after-tax return, these tax reductions were equivalent to about a 13 percent cut in the annual cost of capital. In the latter half of the decade, suspension of the investment tax credit and accelerating capital-goods prices raised the fixed-cost component relative to operating costs.

Throughout the 1960s, steel prices, as shown in column 4, rose at a slightly slower rate than operating costs. The slow rise of capital costs in the early 1960s was reflected in a slight rise in the ratio of price to total costs, but this was reversed in later years. In a comparison of the level of market prices with the calculated supply cost, market prices appear to have been substantially below the level consistent with the 6 percent return on capital used in calculating supply cost. This is not unexpected for an industry plagued by excess capacity.

Between 1970 and 1975, operating costs (excluding environmental) increased by 66 percent and outpaced the general inflation in the nonfarm business sector by 30 percentage points. More than half of this increase was accounted for by a doubling in the cost of raw materials, particularly coal. Employment costs were also 50 percent higher. The inclusion of environmental operating costs would raise the total increase to 73 percent for a new plant meeting 1983 standards.

Despite the 73 percent rise in prices between 1970 and 1975, these calculations suggest that the ratio of price to operating costs was unchanged. Because capital costs have increased at a slower rate, aided by a 15 percent reduction in capital costs because of lower taxes, the profitability of the industry has improved, though it remains below the estimated level implied by a 6 percent return on capital.

The reasonableness of the cost calculations can be roughly checked by reference to income statements for the industry. The ratio of gross income to capital (depreciation interest, net income, and taxes) is measured as a 
ratio to sales. ${ }^{24}$ The use of a gross-income concept avoids the problem of allocating income between profits and replacement-value depreciation. Sales rather than the capital stock is used as a denominator because of problems in revaluing capital recorded on an historical-price basis to a replacement-cost basis. This gross profit margin per dollar of sales was regressed on a time trend and the capacity utilization rate for the steel industry. The resulting coefficient on the utilization rate was then used to adjust the gross return to a standard operating rate. ${ }^{25}$ The adjusted gross margin, shown in column 7, declined by one-fourth between 1965 and 1970, after being roughly constant in the first half of the decade. It rose slightly from 13 percent of sales in 1970 to 14 percent in 1975 ; it was 17 percent in 1974, but this may have reflected a capital gain on inventories; and it was constant at 14 percent throughout the period of controls. This pattern is nearly identical to that derived from the cost index and supports the notion that price increases throughout the 1970 s reflected trends in operating costs. Because the increases in these costs exceeded those in capital costs, a markup form of pricing did narrow the gap between the market price and that calculated to induce expansion.

Some further points can be made about the prospects for capacity growth in the steel industry. First, steel prices have continued to rise in 1976, perhaps narrowing the gap between the market price and the supply cost. Second, some capacity growth can be expected from "rounding out" existing plants at a cost less than the $\$ 375$ per ton (1972 prices) used in these calculations. Third, the industry might undertake expansion without requiring a 6 percent after-tax return on the replacement value of existing capital. The firms within the industry have depreciated the major portion of their existing plant for balance-sheet purposes $;^{26}$ thus, a 6 percent return on replacement cost would imply a very high return on an historical-cost measure of stockholders' equity. Finally, much of the industry's capacity represents investments of the 1940s and 1950s. If technological progress during the period of excess capacity was such that it could not be applied to existing capital, the average cost structure for the industry in 1972 may

24. Ibid., p. 13.

25. This procedure was used to eliminate the cyclical variation in fixed costs per dollar of sales. It was not possible to exclude the effects of capital gains on inventories, but the inventory valuation adjustment declined sharply in 1975 for the economy as a whole.

26. The figure of $\$ 375$ per ton implies a 1972 replacement value of $\$ 32$ billion for AISI firms compared with a net book value of plant of $\$ 14$ billion in their combined balance-sheet statement. 
significantly exceed the total costs of a new plant today. However, absent such technological innovations, the price increases in recent years evidently have not greatly improved incentives to expand.

Aluminum. The historical index of the supply cost for aluminum is shown in table 10. Because no measure of market prices for alumina is available, the costs are based on average price quotes from producers. The assumption that the price paid for electric power (averaging 4.5 mills per kilowatt hour in 1972) changes in line with the WPI for electric power matches well with data from the Census of Manufactures for the available years. The comparison of the estimated supply cost with the WPI for aluminum ingot is also uncertain because realized prices bear scant resemblance to the published price. ${ }^{27}$ Some measure of the variability between actual and quoted prices is provided by the estimates of price realizations for Alcoa, shown in column 5.28

Operating costs (column 1) fell during the first half of the 1960s and then rose slowly for the rest of the decade. This pattern results from a modest decline throughout the period in alumina costs, stable prices for electric power and other materials, and falling unit labor costs in the first half of the decade followed by substantial increases in later years. Although erratic in these data, prices seem to have tracked operating costs fairly closely during the late 1960 s (column 6 ). Their decline relative to costs after 1970 implies a substantial decline in the rate of return. Through 1972, the decline in terms of realized prices appears to have been even more severe because of the extensive use of price discounts.

Aluminum prices increased rapidly after 1973. As shown in column 6, however, the increases were largely a reflection of dramatically higher operating costs: there was very little change in the ratio of list prices to operating costs. On the other hand, because the rise of operating costs far outpaced that of capital costs, a proportionate increase of prices relative to variable costs did result in a significant improvement in overall profitability between 1973 and 1975. By 1975, list prices were only slightly below the supply cost.

27. This problem will be reduced in future years because the WPI is now based on data collected from aluminum buyers.

28. Derived from Standard and Poor's Corporation, Industry Surveys: Metals, Nonferrous, Basic Analysis (November 7, 1974), sec. 2, p. 170; and Chase Econometric Associates, Inc., Aluminum Shortage: An Analysis of the 1973-1974 Experience (Washington, D.C.: National Commission on Supplies and Shortages, 1976), p. 76. 


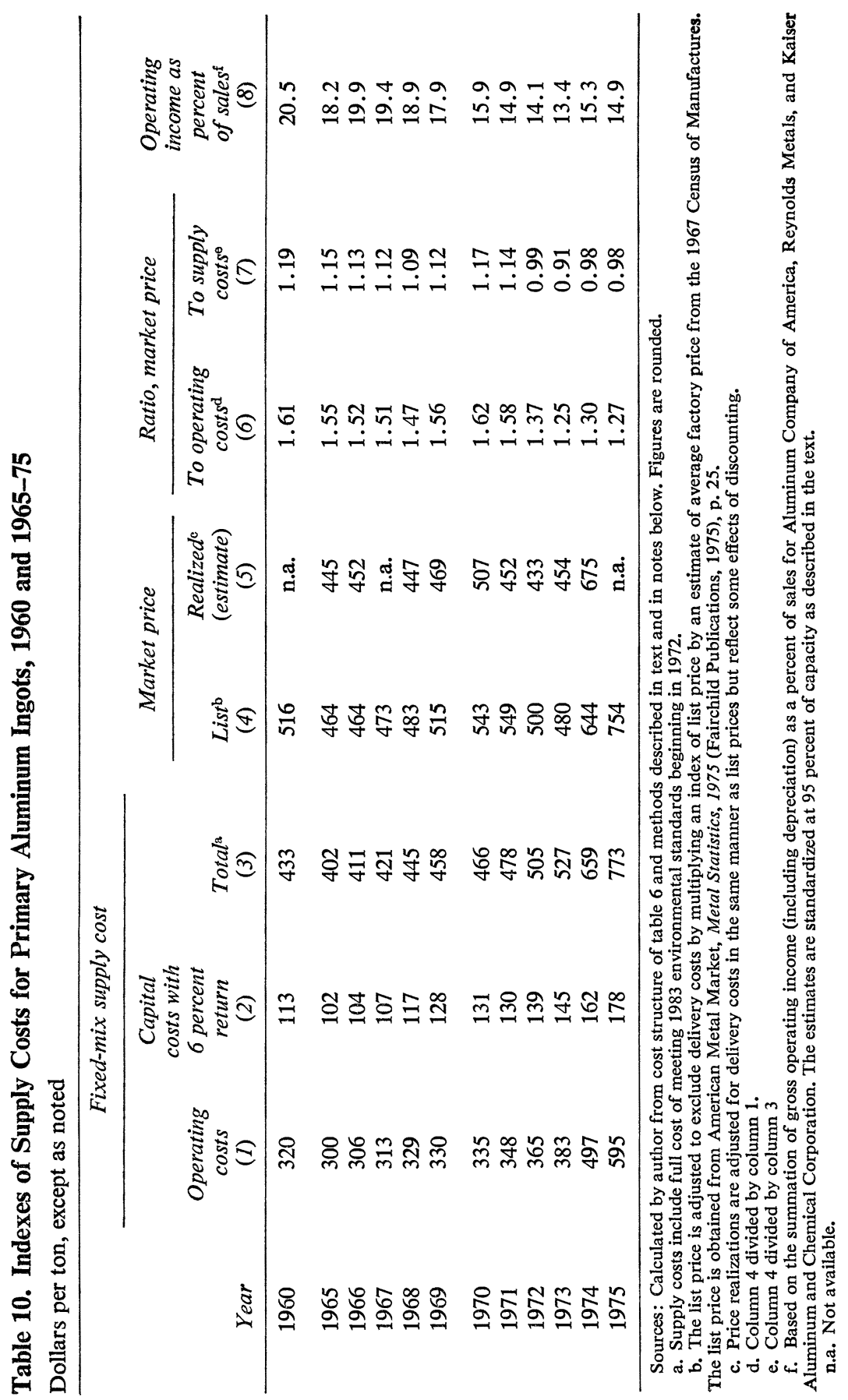


Because the industry pricing pattern seems to have been a proportionate markup over operating costs, prices appear to have covered the rise in capital costs, and created an attractive outlook for expansion. But an extrapolation of the general rise in power costs is inappropriate as a measure of the costs for new aluminum plants. In 1972 the industry paid an average of 4.5 mills per kilowatt hour in purchased electric power compared with an average of about 10 mills for the rest of manufacturing. Attractive sites with low-cost power have been generally unavailable since the late 1960s, and an estimate of 12 to 15 mills seems more realistic for 1975 than the 7.3-mill rate implicit in the above calculations. A 15-mill rate would raise the 1975 estimated supply price of $\$ 773$ by $\$ 108$ per ton..$^{29}$

On the other hand, prices have risen sharply in 1976. In mid-1976, the delivered price for aluminum reached $\$ 960$ per ton compared with the 1975 average of $\$ 754$ per ton shown in table 10. Even with an allowance for some cost increase, these prices would cover a substantial portion of the higher energy costs for new plants.

The basic conclusions about the trend of prices relative to costs can be checked, as with steel, by reference to corporate profit statements. A comparison of the trends of prices and of operating costs implies a general decline in the return on sales during the 1960s, a continuation of the decline in the 1970s on the basis of list prices, and approximately an unchanged margin in the 1970s if the realized price is more representative of actual prices. Although an income statement is not available for the industry as a whole, the ratio of gross operating income to sales of the largest three companies may be representative. ${ }^{30}$ This profit measure was adjusted for

29. A new mill would not face all of these operating costs since it would incorporate substantially lower labor requirements and some energy saving compared to the industry average. Aluminum costs in 1976 are calculated for such a plant at over $\$ 1,000$ per ton (excluding delivery costs) in a recent report on the industry; see "Aluminum Industry First Quarter Review: The 1976-1980 Outlook," The Spector Report-Aluminum Industry Service (New York: Oppenheimer \& Co., Inc., March 8, 1976), p. 19. This implies a list price of 54\& per pound compared with $48 \notin$ in mid-1976 and a $40 \&$ average for 1975. That cost structure reflects lower labor requirements in return for about 7 percent higher capital costs, and it uses a 10 percent after-tax return compared with the 6 percent of tables 9 and 10. But the major difference results from a higher price for alumina. The present study uses producer reports of prices, but they agree closely with the price reported in the Census of Manufactures, in which producers are instructed to include a return to capital.

30. These data were drawn from Standard and Poor's Corporation, Standard Corporation Descriptions, various issues, for Alcoa, Reynolds, and Kaiser. The operations of these firms cover much more than aluminum-ingot production and thus serve only as rough indicators. 
fluctuations in capacity utilization and is shown in column 8 . It reflects the decline of the 1960s, falling from 19.9 percent of sales in 1966 to 14.1 percent in 1972 and 13.4 percent in 1973, and rising slightly thereafter.

The most interesting implication for expansion of domestic capacity in this industry is that a rise in prices in line with operating costs for existing plants may not call out major increases in capacity if new plants face substantially higher costs of power than old ones do. This conclusion implies that existing firms would have to earn an above-normal rate of return on present facilities before new expansion would be undertaken. The aluminum industry has typically operated with a much lower marginal cost of power than other industries. Even a charge of 15 mills per kilowatt hour would be well below the range of 18 to 33 mills reported in the May 1976 wholesale price index for industrial power. If this rate differential was reduced further, major price increases would be needed. The uncertainty about the power contracts in the Northwest, which are due to expire in the early 1980s, also clouds the outlook.

Paper and Paperboard. The historical supply-cost index for the paper and paperboard industry and its comparison with market prices are presented in table 11. The supply cost indicates that average costs increased very modestly throughout the 1960s, but that the rise in supply costs was not fully reflected in prices in the late 1960s and early 1970s.

The sharp increases in the supply cost began in 1972. In part this shift is due to the introduction of pollution-abatement costs into the index in that year. But, in addition, operating costs rose by 46.8 percent between 1971 and 1975. If the private nonfarm deflator of the national income accounts is used as a general relative standard, this rise exceeded general inflation by 16 percentage points.

Costs of fixed capital showed great stability over the 1960-70 period because higher capital-goods prices were largely offset by various tax reductions. However, beginning in the late 1960s, tax reductions no longer offset an accelerating rate of capital-goods prices, and basic fixed-capital costs rose by 30 percent between 1971 and 1975 . When environmental costs are added in, the capital-cost component increased by 41 percent.

As the result of these increases, the total supply cost rose by 45 percent between 1971 and 1975. This is a substantial rate of inflation, but it does not fully account for the 59 percent rise in paper and paperboard prices during the period. Perhaps problems of measuring material costs, or the weights used in constructing the supply-cost index, contribute to this difference, but none of the individual cost indexes indicates an increase of this 


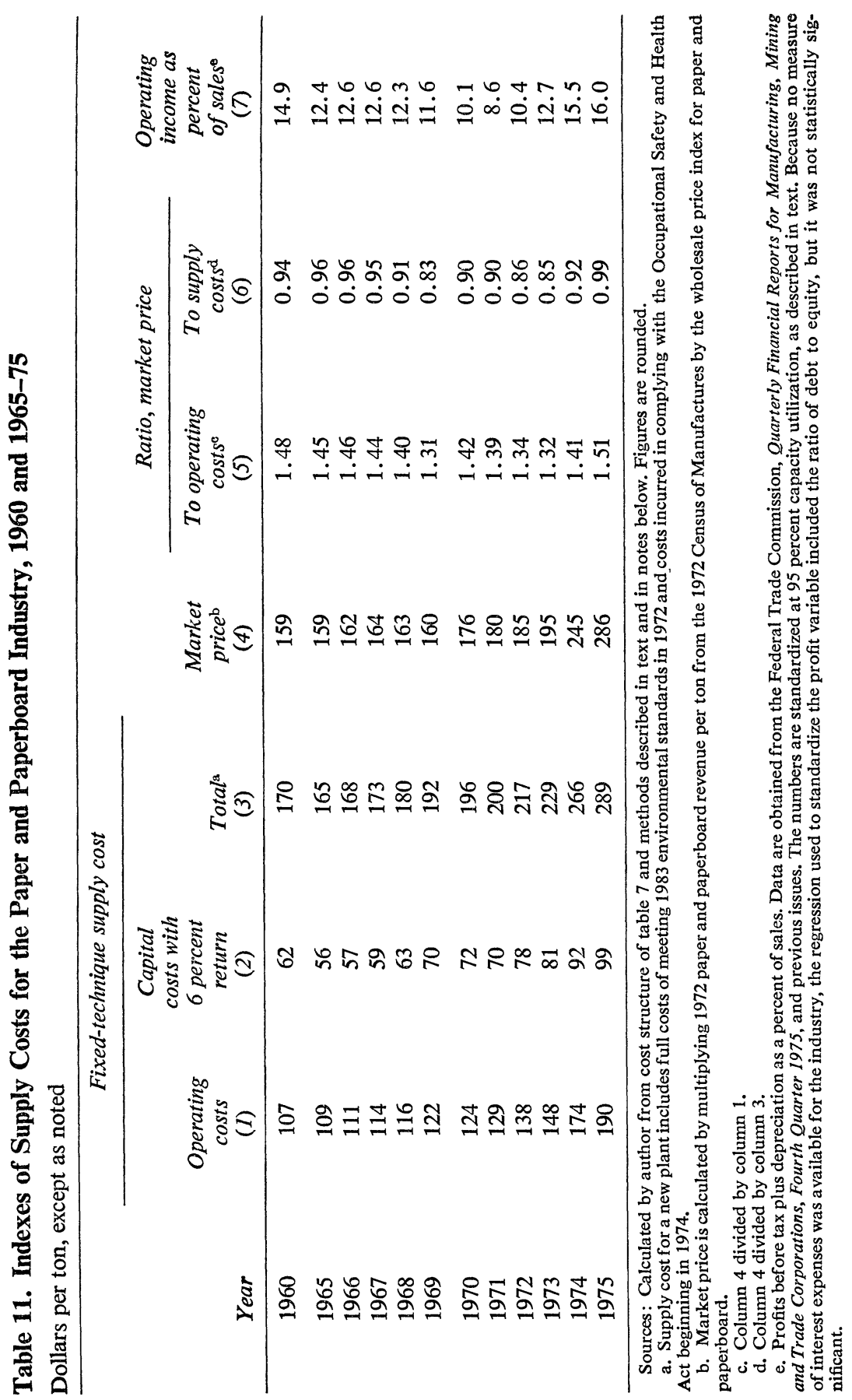


magnitude. The more reasonable conclusion is that prices in the industry have gone up more rapidly than costs, indicating an increased rate of return.

The conclusion that profitability has improved is supported by current income data for the industry. Sales and profit data for corporations whose primary operations are within the paper industry are published by the Federal Trade Commission. The standardized measure of the gross margin is generally consistent with the previous comparison of market prices with the supply-cost index. The margin fell from 12.6 percent of sales in 1967 to 8.6 percent in 1971, reflecting the fact that not all costs were being passed through into higher prices. However, after 1971, the trend was sharply reversed and the standardized margin rose to 16 percent of sales, which is equivalent to the profit margins of the middle 1950s. The increase was not as evident in the actual reported profits of the industry in 1975 because the operating rate was at a recession level of 77.6 percent:

This pattern of change in the implied return to capital is consistent with studies of the overall economy that have identified a declining return in the late 1960s, with some evidence of a reversal in recent years. ${ }^{31}$ At least within the paper industry, the downtrend of prices relative to costs seems to have been reversed, and a return to more normal operating rates would make this evident in reported profits.

The sensitivity of cost to a change in the rate of return on capital can be illustrated with the formula for estimating the rental price of capital. A change of 1 percentage point in the cost of capital (from 6 to 7 percent) would raise the 1975 estimate of the supply cost of paper by 4 percent; coincidentally, this would eliminate the gap between the market price and the supply cost in table 5 .

Despite its large increases, however, the index may still understate the cost of new supply in the paper and paperboard industry. The capital-cost index of table 5 is based on a weighted average of the national income accounts deflator for equipment and structures. These indexes do show a sharp acceleration in capital costs since 1973 (31 percent for structures and 25.4 percent for equipment between 1973 and 1975), but these increases are far less than those reported by the industry.

31. See, for example, Nordhaus, "Falling Share of Profits," and Charles L. Schultze, "Falling Profits, Rising Profit Margins, and the Full-Employment Profit Rate," BPEA, 2:1975, pp. 449-69. Some contrary evidence is presented by Robert J. Gordon, "The Impact of Aggregate Demand on Prices," BPEA, 3:1975, pp. 613-62, and the comments and discussion that follow, pp. 662-70. 
Estimates from the American Paper Institute indicate that construction costs within the pulp, paper, and paperboard industry for a fixed-technology plant (excluding environmental-control costs) increased by 60 percent in the 1970-75 period compared with 45 percent for the economy-wide averages from the national income accounts..$^{32}$ Also, the industry estimates the cost of pollution control at a higher level than the Arthur D. Little study does. If the inflation of capital costs is understated by as much as 15 percent during the 1971-75 period, the supply cost would be raised by an additional 5 percent.

In summary, it seems evident that the higher prices for paper and paperboard cannot be explained solely by higher operating costs for existing plants. The rapidly rising costs of new plant construction have provided an umbrella under which existing firms have been able to raise prices relative to operating costs. It is puzzling, however, that these price increases were posted during the 1974-75 recession rather than being delayed until a period of capacity pressures. These calculations suggest that prices have now risen relative to costs to a point at which the expansion of new capacity is economically attractive. Thus, a proliferation of expansion plans may be expected as the utilization rate recovers from the 1975 recession.

\section{SUMMARY}

The data on costs and prices, as well as those on operating income, tell a similar story for all three of these industries. The ratio of prices to costs, as a measure of expansion incentives, declined throughout the last half of the 1960s and the first few years of the 1970s. In the 1974-75 period all three industries have experienced an improvement in this measure. This rise is most noticeable in the ratio of price to total costs, but it is also evident in operating income. While the rise in prices relative to costs represents a substantial recovery from the disastrous situation of 1973, it has not, except for paper, meant a full return to the profit position of the mid1960s.

Many observers have asserted that the recent large increases in nominal capital costs act as a major deterrent to capacity expansion. The data used in this study of three industries do indicate that inflation and pollutionabatement measures have sharply raised capital costs. The increases in

32. The industry estimates were supplied by Norma Pace of the American Paper Institute. 
operating costs have been even larger, however, and prices tend to follow operating costs more closely than total costs. In the steel and paper industries, prices have risen as fast as, or faster than, operating costs in the last few years, so that the rise in prices has more than covered the higher capital requirements and has actually improved the incentives for new plants. For aluminum, price increases from 1971 to 1975 did not keep pace with operating costs, although they may have caught up in 1976. Much higher capital costs than those of this study have been cited for specific new plants. But such proposals must include considerable substitution of capital for other production costs, since one cannot obtain such estimates by adjusting the costs of existing plants for the rise in construction costs. Thus, the additional capital costs must be offset by reductions in other components of total costs.

Also, the data for these industries do account for the major portion of the large increases in product prices during the 1974-75 recession. Primarily, they were a simple reflection of the enormous rise in operating costs, particularly fuels and raw materials. While the basic price-cost relationship has become more favorable today than it has been for some time, it is not as favorable as it was in the early 1960s. At that time, a decline in capital costs provided strong incentives for expansion, since a new facility could be expected to have lower total costs than existing plants did. In addition, some of the tax cuts of the early 1960s, such as the investment tax credit, were explicitly available only for new equipment.

The falling ratios of prices to operating costs experienced at various times after the mid-1960s by each of these industries, rather than the sharp rise of prices in recent years, is seen as the more puzzling factor in this study. It cannot be accounted for by reference to full-cost pricing models since the decline in capital costs in the early 1960s and their later increase is the reverse of the pattern of price changes. Nordhaus offers one explanation: tax incentives and a declining cost of capital (due to lower risk premiums) sharply stimulated investment and led to excess capacity. ${ }^{33}$ For example, use of his measure of the cost of capital in the cost model of the paper industry would have lowered the annualized capital cost per ton in 1975 by 8 percent. It would have reduced the inflation of this cost component from 14.5 to 7.5 percent between 1960 and 1970 and from 18 percent to 14 percent between 1970 and 1975 . While such a measure lowers the estimated supply cost, it is not sufficient to make a full-cost pricing ex-

33. Nordhaus, "Falling Share of Profits," pp. 192- 204. 
planation fit the pattern of price movements in the late 1960s. Nor can it explain the slowing of the decline in the margin since 1973 for steel and aluminum and its apparent increase in the paper industry. If the decline of the cost of capital led to overexpansion and downward pressure on prices from excess capacity in the late 1960s, there is little evidence of such a condition in paper and aluminum until demand dropped in 1970; and the utilization rate actually drifted upward in the steel industry.

Two other factors are worth noting. First, the gradual overvaluation of the dollar in the late 1960s intensified foreign competitive pressures on these industries and reduced margins on domestic production. The devaluation of 1971 ended that distortion, but price controls may have frozen firms at a low ratio of price to operating costs a while longer. Since 1972, margins have stabilized or widened. Second, a business community accustomed to the stable prices of the early 1960s may simply have been slow to adjust prices with respect to costs during the period of rising inflation rates. Since capital costs seemed stable on an historical-cost accounting basis, it may have taken the extreme inflation rates of 1973-75 to induce a change in pricing policies.

\section{The Outlook}

Although the current incentives for expansion in these three industries appear to be as good as they have been in many years, available data on current projects for capacity expansion indicate that over the next year capacity will be only marginally above 1973 levels. These earlier decisions reflect, primarily, the extremely poor profitability position of 1973-74 and the 1975 recession. As shown in table 12, growth in capacity between 1973 and 1977 is expected to be only 5.2 percent in the steel industry, 8.1 percent in aluminum, and 8.8 percent in paper. These increases are much smaller than the roughly 16 percent growth in potential GNP that is consistent with maintaining a constant unemployment rate for the economy as a whole over this period. Thus, the imbalance between capacity in these industries and the available labor force seems to have worsened considerably since 1973. While one might be reasonably optimistic about current incentives for expansion, the depressed state of these markets in previous years has resulted in a low current level of capacity relative to the rest of the economy. 
Table 12. Production, Capacity, and Capacity Utilization Rates for the Steel, Aluminum, and Paper and Paperboard Industries, Actual, 1973-75, and Forecast, 19\%6-77

Millions of short tons, except as noted

\begin{tabular}{lcccccc}
\hline \multirow{2}{*}{$\begin{array}{l}\text { Industry and } \\
\text { output measure }\end{array}$} & 1973 & 1974 & 1975 & & \multicolumn{2}{c}{ Forecast } \\
\cline { 2 - 3 } \cline { 6 - 7 } & & & & & 1976 & 1977 \\
\hline $\begin{array}{l}\text { Steel } \\
\text { Production }\end{array}$ & 150.8 & 145.7 & 116.6 & & 137.0 & 156.0 \\
Capacity & 155.0 & 155.6 & 156.5 & & 159.0 & 163.0 \\
Utilization rate (percent) & 97.3 & 93.6 & 74.5 & & 86.2 & 95.7 \\
Aluminum & & & & & \\
Production & 4.53 & 4.90 & 3.88 & & 4.31 & 5.00 \\
Capacity & 4.83 & 4.90 & 4.97 & 5.09 & 5.22 \\
Utilization rate (percent) & 93.7 & 100.0 & 78.1 & 84.7 & 95.8 \\
$\begin{array}{l}\text { Paper and paperboard } \\
\text { Production }\end{array}$ & 61.3 & 59.9 & 52.3 & & 61.4 & 64.3 \\
Capacity & 64.5 & 66.1 & 66.8 & & 68.3 & 70.2 \\
Utilization rate (percent) & 95.0 & 90.1 & 78.3 & & 89.9 & 91.6 \\
\hline
\end{tabular}

Sources: Capacity data for 1973-76 are from tables 1, 2, and 3. For the 1976-77 period, capacity is midyear estimates derived from the following sources: (1) steel-American Iron and Steel Institute for 1976, extrapolated to 1977 at same growth rate as for 1975-76; (2) aluminum-derived from end-of-year estimates in "Aluminum Industry First Quarter Review: The 1976-1980 Outlook," The Spector Report-Aluminum Industry Service (New York: Oppenheimer \& Co., Inc., March 8, 1976); (3) paper and paperboard-capacity survey of American Paper Institute. Forecasts of production were supplied by Dick Rippe, Reynold securities, Inc., and are based on demand equations linked to a growth in overall real GNP of 6.4 percent in 1976 and 5.0 percent in 1977 .

Production has already recovered sharply from the depressed conditions of 1975 and the decumulation of excess inventory is completed. Although no serious demand pressures are anticipated in 1976, the projections in table 12 indicate that utilization rates approaching those of 1973 could be reached by early 1978, assuming that overall real GNP will grow 6.4 percent in 1976 and 5.0 percent in 1977, and that the expansion will be led by a strong rise in durable-goods output. Slower economic recovery in other countries could provide, for a time, sufficient excess capacity to allow imports to fill any deficiency in U.S. supply; but, without a rise in expansion plans in the near future, shortages of these materials could become more significant toward the end of the decade.

Any forecast of demand for basic materials is particularly uncertain within the present economic environment, but some conclusions can be drawn. First, domestic capacity in these industries is not adequate to meet the growth in demand associated with policy aimed at sharp reductions in 
unemployment within the next two years. The margin of supply provided during the 1960s by excess steel capacity and the aluminum stockpile has been exhausted. Rates of real GNP growth of 6.5 to 7 percent in 1977-78 would require heavier reliance on imports.

On the other hand, current forecasts of the most likely course of economic expansion do not imply major shortages in these industries. The growth of demand envisaged by the forecasts in table 12 is above that of other recent studies. The projected rise in steel production implies an annual growth rate of 3.2 percent between 1972 and 1977; even allowing for lower import levels today, the projected rise in steel demand is substantially above the long-term trend of less than 2 percent. The growth of demand for paper and aluminum is more moderate relative to past trends, presumably reflecting the impact of the sharp rise in the relative price of these materials. Both of these industries would have larger reserves of capacity than would steel.

Yet, with operating rates not far from peak levels, fears of shortages conceivably could touch off a repeat of the experience of late 1973 and 1974, when inventories accumulated and buyers ordered in excess of needs. Such a situation would be unlikely to cause an explosion in the prices of these products because the historical practice has been to meet such pressures through the backlogging of orders. But such a situation of tight supply could disrupt the flow of materials to and production in other sectors of the economy.

Finally, this study has sought the causes of cost increases and their relation to capacity growth. But the chaotic pattern of demand over the last decade must also have played a major role in creating the present imbalances between capacity and potential demand. For industries that have construction lead times of three to five years, the major errors in estimating needs within the current economic environment are not surprising. The sensitivity of expansion plans to current economic conditions can be illustrated by the intentions of the world aluminum industry for the year 1978 , reported in surveys since the end of $1973 .{ }^{34}$ At the end of 1973, expansion plans implied a growth in capacity of 35 percent between 1973 and 1978. By the middle of 1974 that estimate had moved up to 43 percent. But programs were postponed and canceled over the next eighteen months of

34. "Year-End Survey of Free World Primary Aluminum Capacity, 1975-1980," The Spector Report-Aluminum Industry Service (New York: Oppenheimer \& Co., Inc., February 10, 1976). 
recession, and by late 1975 the estimated growth of capacity was reduced by a third to 28 percent. Similarly, cyclical fluctuations are evident in surveys of expansion plans for the paper and paperboard industry for a horizon beyond two years. However, because of the long construction period involved, within a two-year period there is little scope for varying additions to capacity from the amounts already scheduled.

The erratic cyclical swings from boom to bust over the last decade stand in sharp contrast to the first part of the 1960s, when a steady expansion of overall demand created a far more stable environment for the projection of capacity needs by firms. Whatever incentives for expansion were established by the demand pressures of 1973 were destroyed by the magnitude of the ensuing recession. The results of this study imply that, at least for these industries, readjustment to the requirements of a high-employment economy is likely to take some time. 


\section{Comments and Discussion}

Robert J. Gordon: The problem addressed in Bosworth's paper is important if it motivates economists now advocating policy stimulation to modify their stand. My interest in the problem stems from the contrast between 1969, with its 3.5 percent unemployment rate without noticeable shortages of anything, and 1973, with its 4.9 percent unemployment rate and shortages of almost everything. What caused the imbalance between plant capacity and labor supply in 1973? Will we face the same (or a worse) imbalance in the late 1970s, and, if so, what should we do about it?

My back-of-the-envelope forecast for 1978 is not reassuring. What would be the utilization rates in Bosworth's three industries if the unemployment rate were to fall to an annual average of 5.6 percent, a number chosen to correspond to Michael Wachter's recent estimate of the natural rate of unemployment (BPEA, 1:1976)? It should be emphasized that this exercise is different from the one Bosworth attempts in table 12. Bosworth forecasts utilization rates in 1977 on the likely assumption of modest but not superheated growth. I forecast utilization rates on the unlikely assumption that policy is sufficiently expansive to reduce unemployment to 5.6 percent as the average annual rate during 1978 (this requires a 6.9 percent growth rate of real GNP between the second quarter of 1976 and the end of 1978).

Using some of the data in the paper and applying a fixed-coefficient view of the economy which I shall question shortly, I developed utilization forecasts which are compared below to the highest utilization rate achieved in the periods covered by Bosworth's tables: ${ }^{1}$

1. The main elements of the forecast are as follows: The output projection is based on the assumption that the constant-unemployment level of GNP grows at an annual rate of 3.75 percent between 1974 and 1978. The ratio of durable-goods output to GNP is conservatively set at the "medium" 1972 level, not at the high 1973-74 levels. The 


\begin{tabular}{lccc} 
& 1978 & \multicolumn{2}{c}{ Previous high } \\
\cline { 3 - 4 } Steel & forecast & Level & Year \\
Aluminum & 104 & 97 & 1973 \\
Paper & 120 & 103 & 1965 \\
& 102 & 96 & 1972
\end{tabular}

These startling numbers appear to offer a challenge to those economists who advocate stimulating the economy to achieve rapid output growth. How might the forecasts be wrong?

First, the prices of all three of these commodities have gone up, relative to all durable goods, by 20 to 25 percent since 1972 . What price elasticities would allow these increases in relative prices to reduce utilization rates in 1978 from my fixed-coefficient forecasts to the highest postwar values? The answers are elasticities of roughly -0.12 in steel, -0.33 in aluminum, and -0.12 in paper. A pessimistic view is that these elasticity estimates may be larger than would apply in a situation in which the relative prices of all three materials rose together, even if they look conservative for a situation in which the relative price of only a single material rose. An optimistic view is that automobile manufacturers and others are learning how to substitute away from materials in general toward labor and engineering skill. I want to be optimistic and suggest that we may be able to squeeze through in 1978, but I wonder whether the "shrinking exercise" of the automobile industry is being widely duplicated in other durable-goods industries. In fact, I wonder whether the automobile industry would have invested in shrinkage at all had it been faced only with higher relative prices of materials and not with pressure to economize on fuel.

A second possibility is that a simple extrapolation of capacity growth is incorrect and that unexpected additions to capacity will suddenly appear in 1978. But the recent Commerce investment-anticipation surveys are not reassuring. Total investment plans for the last half of 1976, net of antipollution expenditures and corrected for price changes, are 19 percent be-

ratio of finished-steel consumption to durable-goods output is set at the average of 1969 and 1973, and the import share is set at the 1973 value. The ratio of aluminum consumption to durable-goods output is set at the 1973 value, a conservative assumption in light of the steady historical growth in this ratio. Secondary aluminum recovery is set at the same share of consumption as in 1973. No consumption from stockpiles or imports is assumed. The ratio of paper consumption to GNP is set at the average of the 1969 and 1973 values. Capacity in steel and aluminum is extrapolated from Bosworth's 1977 figure in table 12 by the average 1975-77 growth rate of capacity. Planned 1978 capacity in paper is that reported in the. Wall Street Journal (October 6, 1976), p. 17. 
low 1969 in steel and 5 percent above 1969 in aluminum. Only a 50 percent increase since 1969 in paper suggests any likelihood of substantial capacity expansion in the next few years (and a 6.6 percent capacity expansion in paper from 1975 to 1978 is already assumed in my forecasts).

So the possibility remains that an attempt to push the economy rapidly down to 5.6 percent unemployment in the next two years could force rationing of some of these materials or a price explosion that could tilt the short-run inflation-unemployment tradeoff predicted by most forecasting models.

The last half of Bosworth's paper, designed to tell us how we got into this pickle, is not very convincing. The first purpose of the supply-cost calculations is to examine why the output price in these industries has gone up so much in the last three years. The problem is that there is no way to evaluate the accuracy of the supply-cost estimates. Consider the artificial example of an output price that has increased by exactly the same amount as a supply-cost estimate over the last fifteen years. This doesn't validate the supply-cost estimate, because we do not know ex ante how the ratio of output price to supply cost should behave. One assumes that this "Bosworth ratio" should be positively correlated with profit margins, and table 9 indicates a possible inconsistency in steel, for which profit margins are down substantially from the early 1960s while the Bosworth ratio does not change appreciably. It would be reassuring to know that the Bosworth ratio can be used in econometric work to improve equations for investment in these industries, but variations in capacity growth do not appear related to prior changes in the ratio.

Some might say that the best policy solution to the possibility of a capacity squeeze in basic materials is no solution-that is, let the private economy grind out its own relative prices, which will clear these markets. We are now patiently waiting for the private economy to grind out a price and wage level that will eliminate the present surplus of labor; why should we have complete confidence that it will instantaneously eliminate a shortage of basic materials? In Okun's "auction" markets, prices clear every day, but Bosworth's three industries to some extent behave like Okun's "customer" markets, with slow price adjustment, in which case the problem of excess demand may be solved by rationing less-favored customers.

This is an example of an area in which a modest dose of government planning-in the limited sense of coordination among government agencies-might be beneficial. Different branches of government have gone 
running off in different directions with their own separate, uncoordinated, and possibly inconsistent objectives. For instance, antipollution and health and safety measures have reduced capacity, and so have Federal Reserve stop-go policies which have raised the risk discounts that firms apply to future profit streams.

Faced with a surplus of labor and a shortage of materials capacity, the government should reduce the labor surplus by expanding aggregate demand until skilled workers are at work while subsidizing private on-the-job training to convert unskilled into skilled workers. If private risk discounts are substantially greater than the social discount rate, so that firms refuse to build capacity that the government calculates will be needed to employ surplus labor, the government should hire idle experts to build steel, aluminum, and paper plants that can then be leased or sold to firms when the government produces the aggregate demand that the firms do not expect. Essentially, the government would operate a "Buffer Stock Plant Corporation," acting as a financial intermediary to bridge the gap between its low social discount rate and pessimistically high private discount rates. (A precedent exists in the government-owned, privately operated Defense Plant Corporation.) The government may be able to justify such an institution by trading on its superior knowledge in two areas: (1) it really does intend to stimulate the economy until the natural unemployment rate is reached; and (2) it really does not intend to impose the price controls that many businessmen fear would accompany a return to more normal levels of demand.

John B. Shoven: One can learn a great deal from this paper. Its value lies in the detailed analysis, which also makes it susceptible to some criticism regarding the reliability of the data and procedures. The most surprising and educational finding is the lack of correlation between investment and capacity expansion. As Bosworth comments, this may suggest the need to rethink the role of the investment tax credit as a permanent feature of the tax system. It may also suggest sorting out various types of investment according to their effects.

Having read the paper, however, I still face at least two important, difficult, and largely unanswered questions: First, what is wrong with the economic system that leads to such imbalances in capacity and causes Bosworth to predict bottlenecks as early as a year from now in these important sectors? Certainly no one in this room would predict that the macroecon- 
omy would be overheated or even fully employed nearly so soon. Second, I am not sure that I understand why this is a public-policy issue and I don't really see that predictions by economists are any more reliable than those of the businessmen who are making the investment and capacityexpansion decisions.

To some extent, Bosworth explains what went wrong in 1973 and what might go wrong in the future: he asserts that in 1973, at least in steel and aluminum, demand rose with unexpected rapidity, in part because of the unusual growth in durable-goods output. I think this is a reasonable explanation, particularly since that demand was a surprise not only to these industries but to economists as well.

The long-run story, which I'm not sure I buy, is that these industries have not expanded capacity rapidly because the marginal cost of additional output has exceeded the current price, leaving no incentive for investment. In fact, capacity has expanded very little since 1973; and, since potential output defined in terms of labor has risen a great deal, one would think that, if anything, the capacity bottleneck will be tighter in 1977 and 1978 than in the last cycle.

The question that I do not think the paper answers but that is most relevant both to the experience in 1973-74 and to the prospects is why prices in these industries did not rise even further. That would have induced consumers to conserve on these items, stimulated imports, and lent the incentive for capacity expansion.

I am not a believer in fixed coefficients of production, particularly for overall GNP. Thus, I doubt that the product of the economy is bounded by the first bottleneck it hits; and I think that a price system should warn about such potential bottlenecks and should minimize their effects. I do not know why these prices have not risen further, and maybe they ought to do so. On the other hand, if the price were as high as the marginal cost, these industries might actually have excess capacity. Perhaps, in any case, we should not worry about expanding them. They are particularly energyintensive, pollution-intensive, and capital-intensive. Their share in GNP need not be fixed and, perhaps, should be diminished. The aim might well be a rise in the cost of using their products to encourage the replacement of materials-intensive production by more labor- and engineering-intensive methods in the rest of the economy. This shift has already occurred in automobiles, housing, and other sectors in which materials have become more costly. 
In summary, I am somewhat doubtful about the prediction that shortages will recur soon and most doubtful about whether this is a public-policy question. I acknowledge and would emphasize the need that Bosworth has pointed out to try to smooth business cycles because they have induced periodic bottlenecks and excess capacity; but I do not believe that anything special should be done about the capacity issue in these industries. Bosworth appears to agree with me, since he does not come out in favor of subsidizing these industries in general or their capacity expansion in particular.

\section{General Discussion}

Several discussants addressed the general question of how tight capacity had been in 1973 and would be in a coming expansion. Lawrence Klein offered a pessimistic appraisal, reporting that his work with the Wharton index showed that capacity utilization had been high in 1973 in virtually all industries, not simply those Bosworth had considered. Furthermore, his projections pointed to widespread high operating rates in 1977-78, occurring at historically high levels of unemployment, an assessment that Michael Wachter supported. Bosworth stressed that his forecasts of operating rates in the three industries that he analyzed were not necessarily inconsistent with these projections for the near future, since his forecasts were based on extremely conservative rates of demand growth. He also reiterated his conclusion that price-cost relationships were conducive to capacity growth now, so that any problem raised by today's reading on capacity might be solved before it emerged. Bosworth noted that the evidence on Klein's characterization of 1973 was mixed: while the Wharton index implies high overall levels of utilization that year, the McGraw-Hill measure does not. Indeed, it indicates that overall capacity growth had not slowed down between the 1960s and the 1970s. If Klein's characterization is correct, it implies a sharp slowdown of capacity growth relative to growth of the capital stock after the 1960 s.

The discussion turned to the incentives for capacity growth today relative to earlier periods. Arthur Okun pointed out that it was unrealistic to compare supply cost with current market price as an indicator of incentives to expansion. Firms had to look beyond current market price and base decisions on the market conditions they expected after new capacity was in 
place. However, Daniel Brill argued that, even if long-run considerations dominated decisions to expand capacity, firms needed adequate current margins of prices over costs to help them finance expansion projects. He also believed long-term borrowing costs, which had not declined much in the recession and its aftermath, were a special factor retarding capacity growth at this time, and called for a closer examination of the impact of recent monetary policies on long-term capacity expansion in both the United States and Japan. Wachter contrasted the message he got from the Bosworth paper with the view in Nordhaus' paper (BPEA, 1:1974). Nordhaus had found a drop in the rate of profits and had argued that increasing cyclical stability had reduced uncertainty and induced businessmen to invest at lower expected rates of return. The current situation is different because uncertainty dominates investment decisions and has raised required rates of return. Businessmen are uncertain about the prices of their inputs, especially energy; about the long-run elasticities of demand for their outputs in the face of large price changes; about government regulations and environmental controls. Above all, however, they fear the possible imposition of price controls. Paul Samuelson pointed out that some past inhibitions to capacity growth were now greatly diminished. Before the devaluation of the dollar, the steel industry had felt itself at a perennial competitive disadvantage relative to foreign producers. In recent years, industries such as paper had improved their profitability in the face of the deepest postwar recession. Such changes favorable to capacity growth had to be weighed alongside the uncertainties in the present environment cited by Wachter.

The discussion emphasized the importance of sustained real growth for stimulating capacity additions. Samuelson reasoned that businessmen today were concerned that the government would react with contractionary policies as soon as the inflation rate increased, so that new capacity would prove to be unneeded and unprofitable. Bosworth stressed his belief that stop-go policies inhibit capacity growth. Plans for expansion are dropped during recessions. This was true of the paper industry in 1970 and the aluminum industry in 1974-75. He believed that attempts to cure inflation by recession contribute to even higher inflation in the future because of their impact on capacity growth.

Richard Cooper suggested that speculative demand for raw materials rather than capacity shortages could explain the price increases of 1973-74. This alternative hypothesis might be tested by comparing the price in- 
creases for raw materials and processed products. He noted that prices had risen sharply, not only in the industries Bosworth analyzed, but also in many others that had shown no evidence of capacity shortages. Furthermore, the declines in net U.S. imports of aluminum and steel in 1973 were highly unusual for a boom year. Although the dollar devaluation might have played some role in this decline, this evidence points to the existence of strong demand, including speculative demand, elsewhere. He felt that to complete his story, Bosworth would have to find evidence of capacity shortages elsewhere in the world.

Robert Hall believed that the concern over bottlenecks was exaggerated, because increased imports would alleviate them. Others pointed out that the synchronization of the international business cycle had reduced the importance of other countries as sources of supply; their capacity would be tight at the same time ours was, repeating what may have been the 1973 experience. Robert J. Gordon added that the devaluation of the dollar meant that cheap imports were no longer available. But Samuelson noted the other side of this coin: the dollar devaluation had improved the competitive situation of American industry and would encourage expansion for the first time in many years. Lawrence Krause noted that Bosworth's supply-cost numbers, by assuming fixed coefficients, ignored the savings that new technologies would bring about on raw material and labor inputs, and thus understated the incentives to capacity addition that today's prices provided.

Several participants discussed whether special government policies, such as Gordon had suggested, were called for to deal with capacity problems. Charles Holt offered several suggestions: antitrust measures aimed at producers of basic materials who also dominated the distribution of imports; a system something like that used in Sweden, under which the government sets aside a portion of corporate taxes and then determines when and how this should be released for investment spending; and taxes on multipleordering practices. Brill stressed the need for lower long-term interest rates rather than any special programs. John Shoven questioned the premise that the government should intervene in this instance. He emphasized his faith in the price system and argued that the uncertainties that might make businessmen cautious about expanding reflected social as well as private risks. He did not believe that economists could do better than the industries themselves in forecasting the demands for their products. Okun elaborated upon this point, asking why private firms were not enlarging their inventory 
holdings if predictable shortages were imminent. Gordon replied that the government might indeed be better informed than private investors, especially in situations in which the uncertainties hinged on government policies. $\mathrm{He}$ also questioned relying on the price system, when, as Bosworth had pointed out, shortages probably would be dealt with by multiple-ordering practices and rationing. Robert Solow maintained that the monetary authorities were likely to ignore the difference between relative price adjustments needed to eliminate individual shortages and a general rise in prices. They would intervene before the system had time to "grind out its solution," thus causing another recession. Bosworth had sympathy for Shoven's viewpoint, but felt that the contagious nature of fears about shortages was a reason for concern. Once fears of shortages get started, they are difficult to stop, as they were in 1974 before the deepening recession brought them to a halt. 